\title{
Z działalności najstarszej placówki poradnictwa psychologiczno-pedagogicznego w Poznaniu
}

\begin{abstract}
On the Activities of the Oldest Institution of Psychological and Educational Counselling in Poznań

The oldest institution of psychological and pedagogical counselling in Poznań has been operating for almost sixty years. We are referring to the Psychological and Pedagogical Clinic for Children and Young People with Special Educational Needs, currently located on Ulica 28 Czerwca, 1956, no. 296/298. It's origins date back to 1957, when the efforts of the school authorities and academic circles in Poznań created the Psychological Clinic in Poznań. Since it started operating to the present day almost everything has changed. The institution has been subject over the years to numerous reforms, be they administrative, educational, or to the system of providing psychological and educational assistance. The name of the institution has changed four times, the range of tasks has been repeatedly redefined, continually expanding, and the supervising authorities and area of operation have changed. Undeniably, though, it has always played an extremely important role for the children and young people under its care, providing vital real life.
\end{abstract}

Keywords: clinic, educational counselling, professional counselling, help psychological-educational, special educational needs

\section{Poradnia Psychologiczna w Poznaniu (1957-1967)}

Powołanie pierwszej placówki poradnictwa psychologiczno-pedagogicznego w Poznaniu nastąpiło w specyficznych okolicznościach społeczno-politycznych. Na przełomie lat 40. i 50. ubiegłego wieku funkcjonował system, który starał się podporządkować sobie i kontrolować wszystkie dziedziny życia w Polsce. Administracja państwowa dążyła do scentralizowania wszelkiej działalności opiekuńczo-wychowawczej, upaństwowienia wszystkich placówek prowadzonych przez zrzeszenia wyznaniowe i świeckie. Sukcesywnie ograniczano działalność, a wreszcie zlikwidowano szereg organizacji społecz- 
nych i stowarzyszeń. Nastąpił również regres w psychologii, będącej podstawą poradnictwa.

W ocenie władz komunistycznych cała nauka była „reakcyjna”, starano się więc wprowadzić do wszystkich jej dziedzin zasadę „,partyjności nauki”. Na skalę masową prowadzono propagandę i indoktrynację. Jedynie słuszną prawdą naukową był marksizm. Upartyjnianie nauki oznaczało więc odrzucenie większości dotychczasowego dorobku nauki polskiej, odcięcie jej od nauki światowej, zwłaszcza zachodniej i oparcie się wyłącznie na marksizmie-leninizmie. Nauka miała mieć charakter ideologiczno-propagandowy².

Szczególny nacisk wywierano na nauki społeczne, w tym psychologię. Odrzucono wszelkie tradycje i osiągnięcia polskiej psychologii z okresu dwudziestolecia międzywojennego. Zdyskwalifikowano wyniki pracy psychologów zachodnioeuropejskich i amerykańskich. Zakazano stosowania testów i standaryzowanych metod diagnozy psychologicznej, uznanych za narzędzia ślepej klasyfikacji, prowadzonej w oderwaniu od sytuacji społecznej i kulturowej człowieka . Badania psychologiczne kojarzyły się z wyszukiwaniem różnic między ,równymi” ludźmi, co nie podobało się komunistycznym władzom. Według nich psychologia stosowana w poradnictwie utwierdzała przedwojenny, kapitalistyczny porządek. Selekcja i dobór zawodowy stały w sprzeczności z ideą społeczeństwa bezklasowego. W tej sytuacji psychologia jako nauka straciła bardzo na znaczeniu, a zmiany $\mathrm{w}$ jej postrzeganiu odbiły się bezpośrednio na teorii i praktyce poradnictwa. Poradnictwo, jako działanie na rzecz osób słabszych i bezradnych było niepotrzebne.

Do roku 1956 trwała sytuacja zaprzeczania istnieniu potrzeby poradnictwa psychologiczno-pedagogicznego. Dopiero wydarzenia „przełomu październikowego” stworzyły bardziej sprzyjające warunki. Pozwolono sobie na wskazanie błędów w organizacji szkolnictwa zawodowego, skrytykowano oddzielenie szkół zawodowych od resortu oświaty, pozbawienie młodzieży poradnictwa, czego efektem był wysoki odsiew uczniów tego typu szkół. Do łask wróciła również psychologia, zelżała ostra krytyka trwająca od końca lat 40. Wtedy też otwarły się nowe możliwości rozwoju poradnictwa.

Tworzenie instytucji poradnictwa w latach 1957-1964 w Poznaniu związane było z działalnością przedstawicieli psychologii i pedagogiki z Uniwersytetu im. Adama Mickiewicza. Znaczący wkład w teorię i praktykę orientacji i poradnictwa zawodowego oraz poradnictwa wychowawczego wniosły badania nad problematyką dzieci i młodzieży prowadzone przez Stefana Błachowskiego, Bolesława Hornowskiego, Stanisława Szajka, Stanisława Kowalskiego, Zbigniewa Tyszki, Marii Tyszkowej, Heliodora Muszyńskiego,

\footnotetext{
1 Więcej na temat nauki polskiej w okresie stalinizmu w: R. Herczyński, Spętana nauka. Opozycja intelektualna w Polsce 1945-1970, Warszawa 2008; P. Hübner, Nauka polska po II wojnie światowej - idee i instytucje, Warszawa 1987; J. Kossecki, Wpływ totalnej wojny informacyjnej na dzieje PRL, Kielce 1999.

2 Por. J. Kossecki, op. cit., s. 203-220.

${ }^{3}$ K. Obuchowski, Analiza i ocena stanu psychologii klinicznej w dwudziestym roku Polski Ludowej, „Przegląd Psychologiczny” 1965, nr 10, s.121.
} 
Barbary Rosemann ${ }^{4}$. Poza rozwojem teorii poradnictwa istotne było bezpośrednie zaangażowanie pracowników nauki w praktyczną działalność poradni.

W 1957 r. dzięki staraniom władz szkolnych oraz środowiska akademickiego utworzono Poradnię Psychologiczną w Poznaniu. Jej organizacji i kierownictwa podjął się dr Bolesław Hornowski, docent w Katedrze Psychologii ${ }^{5}$. Miał już doświadczenia poradniane, ponieważ w pierwszych latach po II wojnie światowej pracował w Poradni Zawodowej przy Urzędzie Zatrudnienia w Poznaniu. Placówkę utworzoną w 1957 r. nazywano także: Poradnią Psychologiczno-Zawodową, Wojewódzką Poradnią Psychologiczną oraz Poradnią Zawodową dla Młodzieży ${ }^{6}$. Po dwóch latach, w 1959 r., jej kierownictwo objęła dr Barbara Rosemann, także psycholog. Prowadziła poradnię, pomimo różnych zmian organizacyjnych, przez kolejnych czternaście lat. Brakuje jednak szczegółowych danych na temat stanu zatrudnienia i wykształcenia pozostałych pracowników poznańskiej placówki .

Działalność Poradni Psychologicznej w Poznaniu uregulowało wkrótce Zarządzenie Ministra Oświaty z 16 kwietnia 1958 r. w sprawie utworzenia poradni psychologicznych. $\mathrm{Na}$ jego podstawie w poradni powinni być zatrudniani: kierownik, psychologowie - nauczyciele, lekarz - specjalista w dziedzinie poradnictwa zawodowego i pracownik administracyjny. Do ich zadań należało:

1) prowadzenie tzw. preorientacji zawodowej dla młodzieży i rodziców, czyli: popularyzowanie znajomości zawodów, zasad właściwego doboru zawodowego i kształcenia zawodowego,

2) badanie przydatności zawodowej młodzieży z punktu widzenia zainteresowań, właściwości fizycznych i psychicznych,

3) badania psychologiczne młodzieży z trudnościami wychowawczymi i trudnościami w nauce,

4) analiza zawodów z punktu widzenia wymagań fizycznych i psychicznych,

5) opracowywanie nowych metod badań psychologicznych,

6) szkolenie nauczycieli i lekarzy szkolnych w zakresie poradnictwa zawodowego ${ }^{8}$.

Poradnia Psychologiczna była placówką oświatowo-wychowawczą, pełniła również funkcje badawcze i szkoleniowe. Podstawowym celem jej działania były jednak ,,pre-

${ }^{4}$ S. Szajek, Miejsce nauki w rozwoju i doskonaleniu poradnictwa wychowawczo-zawodowego, w: Poradnictwo wychowawczo-zawodowe $w$ systemie oświaty $i$ wychowania. Materialy z konferencji wieńczacej XX lecie poradnictwa wychowawczo-zawodowego w województwie poznańskim 23.X.1978 r., Poznań 1979, s. 23.

5 J. Hellwig, Poradnie wychowawczo-zawodowe w województwie poznańskim 1958-1978, w: Poradnictwo wychowawczo-zawodowe $w$ systemie oświaty $i$ wychowania. Materiaty z konferencji wieńczacej XX lecie poradnictwa wychowawczo-zawodowego $w$ województwie poznańskim 23.X.1978 r., Poznań 1979, s. 64.

${ }^{6}$ Ibidem, s. 64 i 76.

${ }^{7}$ Nie odnaleziono dokumentacji dotyczącej funkcjonowania poznańskiej Poradni Psychologicznej w zbiorach: Archiwum Zakładowego Kuratorium Oświaty w Poznaniu, Archiwum Zakładowego Wielkopolskiego Urzędu Wojewódzkiego w Poznaniu, Archiwum Państwowego w Poznaniu, ani też w Archiwum Zakładowym Poradni Psychologiczno-Pedagogicznej dla Dzieci i Młodzieży ze Specjalnymi Potrzebami Edukacyjnymi w Poznaniu, wywodzącej się bezpośrednio z ówczesnej Poradni Psychologicznej.

8 § 5 Zarządzenia Ministra Oświaty z 16 kwietnia 1958 r. w sprawie utworzenia poradni psychologicznych (Dz. Urz. Min. Ośw. 1958, nr 6, poz. 65). 
orientacja" i poradnictwo zawodowe. Psycholodzy poradni zobowiązani byli popularyzować wiedzę o zawodach wśród uczniów i rodziców przez: pogadanki, odczyty zawodoznawcze, publikacje, artykuły w prasie codziennej i młodzieżowej, programy radiowe i telewizyjne, opracowania monografii zawodów, organizację wycieczek do zakładów pracy, na wystawy szkolne i przemysłowe, wyświetlanie filmów zawodoznawczych itp. Natomiast podczas badań psychologicznych przydatności poszczególnych kandydatów do zawodu stosowali następujące metody i narzędzia pracy: testy psychologiczne, testy wiadomości, kwestionariusze zainteresowań i upodobań, ankiety życzeń zawodowych, rozmowy z badanymi i rodzicami, wywiady środowiskowe, badania lekarskie, analiza wytworów szkolnych ucznia, informacje ze szkoły o postępach w nauce, zachowaniu i zaangażowaniu w zajęcia pozalekcyjne9.

Obszar działania Poradni Psychologicznej w Poznaniu obejmował całe województwo poznańskie. Dlatego niezbędna była współpraca z administracją oświatową, szkołami, organami planowania gospodarczego, urzędami zatrudnienia. Prowadzono szkolenia dla nauczycieli, instruowano ich i wspierano w celu zapewnienia preorientacji zawodowej całej młodzieży kończącej szkoły podstawowe lub średnie ${ }^{10}$. Natomiast kontakt z instytucjami rynku pracy zapewniał informacje na temat zapotrzebowania na kadry w poszczególnych sektorach gospodarki oraz możliwość analizy aktualnej sytuacji i prognozowania w zakresie możliwości zatrudnienia. Poradnia psychologiczna nie zajmowała się jednak kierowaniem do pracy, a tylko kwestią wyboru szkoły i zawodu. Miała obowiązek udzielenia pomocy w dokonywaniu takiego wyboru, z jej usług korzystała więc także młodzież studiująca lub pracująca. Prowadzono także poradnictwo wobec młodzieży niepełnosprawnej fizycznie, przewlekle chorej, upośledzonej umysłowo. Jednak ze względu na ograniczone możliwości jednej placówki, badania przydatności zawodowej nie były obowiązkowe dla każdego ucznia, przeprowadzano je, gdy zachodziła taka potrzeba.

Wobec dużego zapotrzebowania na profesjonalne poradnictwo zawodowe władze oświatowe zakładały jego upowszechnienie przez systematyczne zwiększanie liczby placówek $^{11}$. W województwie poznańskim również starano się rozszerzyć możliwości oddziaływania poradnictwa na większy obszar. W tym celu w roku 1961 powołano filię poznańskiej poradni w Kole ${ }^{12}$. Poradnia Psychologiczna w Poznaniu z filią w Kole była jednak jedyną placówką założoną i bezpośrednio podległą władzom szkolnym w województwie poznańskim ${ }^{13}$.

\footnotetext{
${ }^{9}$ Kwestionariusz - ankieta dot. organizacji poradnictwa zawodowego [odpowiedź na ankietę Międzynarodowego Biura Nauczania, 1960-1962], AAN, Ministerstwo Oświaty w Warszawie, sygn. 674, s. 30.

${ }^{10}$ Por. Okólnik Ministra Oświaty nr 9 z dnia 8 kwietnia 1957 r. w sprawie przygotowania młodzieży w szkołach podstawowych do wyboru zawodu (Dz. Urz. Min. Ośw. 1957, nr 4, poz. 47).

${ }_{11}$ Pismo Kierownika Sekcji Poradnictwa Zawodowego z dn. 8.03.1960 r. do Gabinetu Ministra w sprawie organizacji poradnictwa zawodowego, AAN, Ministerstwo Oświaty w Warszawie, sygn. 674, s. 18.

12 Źródła wywołane: wywiad z dn. 16.07.2009 r. z Marianem Bolewskim - wieloletnim pracownikiem i kierownikiem placówek poradnictwa w Kole.

${ }^{13}$ Zestawienie - Liczba poradni przy K.O.S. i TPD, AZG TPD, sygn. I 37/9.
} 


\section{Okręgowa Poradnia Wychowawczo-Zawodowa (1967-1975)}

$\mathrm{Na}$ początku lat 60. Ministerstwo Oświaty podjęło działania mające na celu udoskonalenie systemu orientacji szkolnej i zawodowej. Podstawowy krok w tym kierunku stanowiła Ustawa z dnia 15 lipca 1961 r. o rozwoju systemu oświaty i wychowania ${ }^{14}$. Wyznaczyła ona szkołom i placówkom oświatowym szeroki zakres oddziaływań. W 1964 r., w nawiązaniu do art. 26 ustawy, Minister Oświaty wydał zarządzenie w sprawie organizacji nowego typu poradni, powołując poradnie wychowawczo-zawodowe ${ }^{15}$. Podkreślono konieczność całościowego ujmowania problemów dzieci i młodzieży. Utworzono placówki, które miały udzielać pomocy zarówno w rozwiązywaniu trudności wychowawczych, jak i porad w sprawie wyboru zawodu. Zaczęto w ten sposób ujednolicać i centralizować system poradnictwa w Polsce.

W 1964 r., na początku procesu integracji i ujednolicania poradnictwa, w ówczesnym województwie poznańskim pracowało ogółem jedenaście instytucji. Było to dziewięć poradni społeczno-wychowawczych ${ }^{16}$ Towarzystwa Przyjaciół Dzieci oraz opisywana oświatowa poradnia w Poznaniu i jej filia w Kole ${ }^{17}$. Na mocy porozumienia Kuratorium Okręgu Szkolnego Poznańskiego oraz Zarządu Głównego i Zarządu Okręgu TPD władze oświatowe przejęły w latach 1966-1968 poradnie od TPD. Jednocześnie rozpoczęto zakładanie nowych poradni wychowawczo-zawodowych. W rejonie oddziaływania Kuratorium Okręgu Szkolnego Poznańskiego planowano uruchomienie około 30 nowych poradni, aby w każdym powiecie działała przynajmniej jedna placówka ${ }^{18}$.

Dopełnieniem sieci poradnictwa wychowawczo-zawodowego było przekształcenie z dniem 1 lutego 1967 r. pierwszej oświatowej Poradni Psychologicznej w Poznaniu w Okręgową Poradnię Wychowawczo-Zawodową (OPWZ) i powierzenie jej funkcji koordynacyjnych na terenie Kuratorium Okręgu Szkolnego Poznańskiego ${ }^{19}$. Jej filię w Kole połączono z przejętą poradnią TPD, tworząc jedną placówkę ${ }^{20}$. Do podobnego rozwiązania organizacyjnego powrócono jednak ponownie w 1974 r., gdy w celu rozszerzenia zasięgu działania poradni w Poznaniu na powiat powołano filię Okręgowej Poradni Wychowawczo-Zawodowej w Tarnowie Podgórnym ${ }^{21}$. Do roku 1975, gdy przeprowadzono

14 Ustawa z dnia 15 lipca 1961 r. o rozwoju systemu oświaty i wychowania (Dz. U. 1961, nr 32, poz. 160).

15 Zarządzenie Ministra Oświaty z dnia 1 sierpnia 1964 r. w sprawie organizacji poradni wychowawczozawodowych (Dz. Urz. Min. Ośw. 1964, nr 10, poz. 108).

${ }^{16}$ Poradnie społeczno-wychowawcze TPD funkcjonowały w następujących miejscowościach: Gnieźnie, Koninie, Chodzieży, Ostrowie Wlkp., Kaliszu, Środzie, Kole, Poznaniu i Pile.

${ }_{17}$ Zestawienie - Liczba poradni przy K.O.S. i TPD, AZG TPD, sygn. I 37/9.

${ }_{18}$ Por. Ministerstwo Oświaty i Szkolnictwa Wyższego. Analiza działalności poradni wychowawczo-zawodowych opracowana na podstawie sprawozdań statystycznych kuratoriów okręgów szkolnych za rok szkolny 1966/67 [972/67/sn], s. 2, AZG TPD, sygn. I 3J/12.

19 J. Hellwig, Poradnie wychowawczo-zawodowe..., s. 77.

20 Źródła wywołane: wywiad z dn. 16.07.2009 r. z Marianem Bolewskim - wieloletnim pracownikiem i kierownikiem placówek poradnictwa w Kole.

${ }^{21}$ Metryczki poradni psychologiczno-pedagogicznych, AZ KO w Poznaniu, Poradnictwo psychologicznopedagogiczne 2000-2003, sygn. 198/423; J. Hellwig, Poradnie wychowawczo-zawodowe..., s. 109. 
w kraju reformę administracyjną, sieć poradnictwa na terenie Wielkopolski ukształtowała się w liczbie: 1 poradnia okręgowa z 1 filią, 29 poradni powiatowych, 6 poradni miejskich. Okręgowa Poradnia Wychowawczo-Zawodowa koordynowała więc pracę 36 jednostek (por. tab. 1).

Tabela 1. Sieć poradnictwa wychowawczo-zawodowego na terenie Kuratorium Okręgu Szkolnego Poznańskiego w roku 1975 (przed reformą administracyjną)

\begin{tabular}{|c|c|c|c|c|c|}
\hline Lp. & $\begin{array}{c}\text { Poradnia } \\
\text { (rodzaj, siedziba) }\end{array}$ & $\begin{array}{c}\text { Rok } \\
\text { założenia }\end{array}$ & Lp. & $\begin{array}{c}\text { Poradnia } \\
\text { (rodzaj, siedziba) }\end{array}$ & $\begin{array}{c}\text { Rok } \\
\text { założe- } \\
\text { nia }\end{array}$ \\
\hline 1 & $\begin{array}{l}\text { Okręgowa PWZ w Poznaniu } \\
\text { + filia w Tarnowie Podgórnym }\end{array}$ & $\begin{array}{c}1957 \\
(1974)\end{array}$ & 19 & Powiatowa PWZ w Kościanie & 1967 \\
\hline 2 & Powiatowa PWZ w Gnieźnie & 1958 & 20 & Powiatowa PWZ w Krotoszynie & 1968 \\
\hline 3 & Powiatowa PWZ w Koninie & 1958 & 21 & Powiatowa PWZ w Lesznie & 1968 \\
\hline 4 & Powiatowa PWZ w Ostrowie Wlkp. & $1958 / 1959$ & 22 & Powiatowa PWZ w Ostrzeszowie & 1968 \\
\hline 5 & Powiatowa PWZ w Chodzieży & 1959 & 23 & Powiatowa PWZ w Pleszewie & 1970 \\
\hline 6 & Powiatowa PWZ w Kaliszu & 1959 & 24 & Powiatowa PWZ we Wrześni & 1970 \\
\hline 7 & Powiatowa PWZ w Środzie Wlkp. & 1960 & 25 & Powiatowa PWZ w Wolsztynie & 1970 \\
\hline 8 & Powiatowa PWZ w Kole & 1961 & 26 & Powiatowa PWZ w Słupcy & 1971 \\
\hline 9 & Miejska PWZ Poznań-Stare Miasto & 1961 & 27 & Powiatowa PWZ w Turku & 1971 \\
\hline 10 & Powiatowa PWZ w Pile & 1961 & 28 & Powiatowa PWZ w Czarnkowie & 1971 \\
\hline 11 & Miejska PWZ Poznań-Grunwald & 1965 & 29 & Powiatowa PWZ w Międzychodzie & 1971 \\
\hline 12 & Miejska PWZ Poznań-Wilda & 1965 & 30 & Powiatowa PWZ w Jarocinie & 1972 \\
\hline 13 & Miejska PWZ Poznań-Jeżyce & 1966 & 31 & Powiatowa PWZ w Obornikach & 1972 \\
\hline 14 & Miejska PWZ Poznań-Nowe Miasto & 1966 & 32 & Powiatowa PWZ w Kępnie & 1973 \\
\hline 15 & Powiatowa PWZ w Trzciance & 1966 & 33 & Powiatowa PWZ w Gostyniu & 1973 \\
\hline 16 & Powiatowa PWZ w Wągrowcu & 1967 & 34 & Miejska PWZ Poznań-Górczyn & 1973 \\
\hline 17 & Powiatowa PWZ w Śremie & 1967 & 35 & Powiatowa PWZ w Szamotułach & 1973 \\
\hline 18 & Powiatowa PWZ w Nowym Tomyślu & 1967 & 36 & Powiatowa PWZ w Rawiczu & 1974 \\
\hline
\end{tabular}

PWZ - Poradnia Wychowawczo-Zawodowa

Źródło: Opracowanie własne na podstawie materiałów archiwalnych i źródeł wywołanych.

Pomimo wiodącej roli Okręgowej Poradni Wychowawczo-Zawodowej w Poznaniu i wyraźnego rozwoju podległej jej sieci poradnictwa, placówka ta borykała się również 
Fot. 1. Budynek przy ul. 27 Grudnia 19 w Poznaniu, w którym mieściła się Okręgowa Poradnia Wychowawczo-Zawodowa

Źródło: Zbiory własne autorki

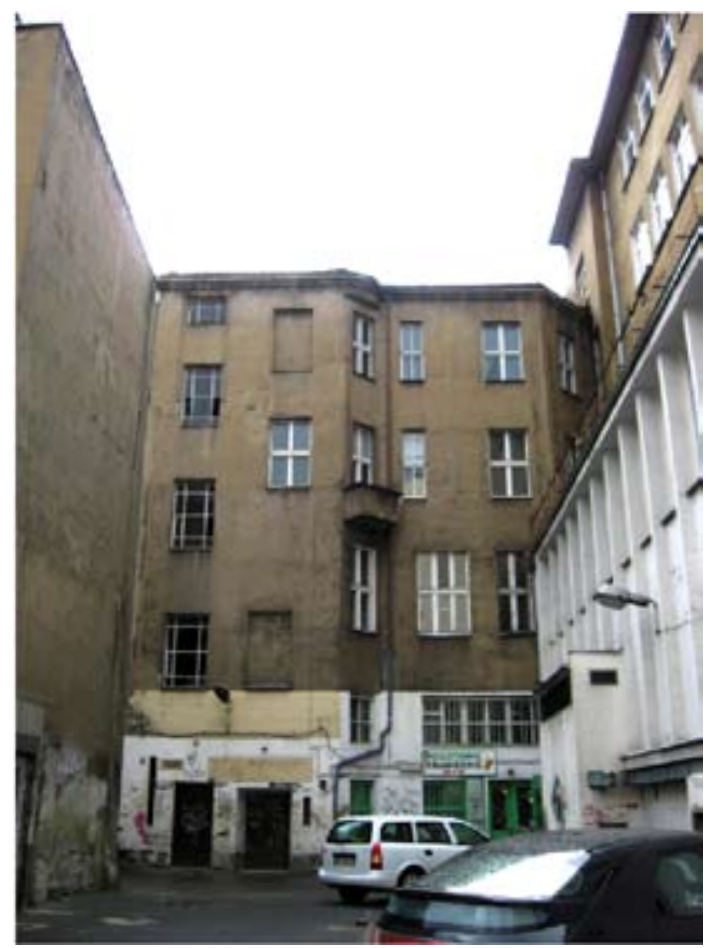

z problemami, głównie lokalowymi. Zapewnienie odpowiednich warunków lokalowych i wyposażenia wymagało bowiem od terenowych władz oświatowych dużych nakładów finansowych, którym nie mogły sprostać.

Od grudnia 1964 r. poradnia okręgowa zajmowała pomieszczenia na drugim i trzecim piętrze kamienicy przy ul. 27 Grudnia 19 (fot. 1). Było to 6 pokoi wygrodzonych z większych sal, problemem było więc ich ogrzanie i oświetlenie - zwłaszcza w sezonie zimowym. Urządzenia sanitarne znajdowały się na klatce schodowej i były wspólne dla użytkowników trzech pięter. Najbardziej uciążliwe było jednak wejście do placówki. Można się było do niej dostać tylko od strony podwórza, przez bramę wjazdową, z której korzystały samochody kasyna MO „Konsumy”, firmy „Eldom” i innych zakładów pracy. Wejście do poradni było jednocześnie wejściem do kuchni kasyna; na podwórze przywożono towar, dokonywano rozładunku; trudno było utrzymać tam porządek. Jak pisał dyrektor placówki do kuratorium, taka lokalizacja poradni, mimo że jest korzystna ze względu na położenie (centrum miasta), absolutnie nie nadaje się dla tego typu placówki [...]; najlepszym obiektem byłby samodzielny budynek willowy o około 15 pomieszczeniach (350$\left.400 \mathrm{~m}^{2}\right)^{22}$.

${ }^{22}$ Pismo Dyrektora OPWZ w Poznaniu z dn. 21.09.1973 r. do KOSP w sprawie lokalu poradni, APP, Prezydium Wojewódzkiej Rady Narodowej w Poznaniu 1950-1970, sygn. 3978, s. 157-158. 
W sprawie nowego lokalu wnioskowano do władz miejskich i partyjnych. Uzasadniano konieczność pozyskania pomieszczeń na: gabinety psychologiczne do badań indywidualnych, badania pedagogiczne, metodyczny gabinet orientacji szkolnej i zawodowej, metodyczny gabinet reedukacyjny, gabinet leczenia nerwic, gabinet prac postkonsultacyjnych. Ponadto z uwagi na zobowiązanie poradni okręgowej do prowadzenia szkoleń dla pracowników wszystkich poradni terenowych niezwykle przydatna byłaby sala wykładowa. Potrzebny był także magazyn testów i druków, ponieważ placówka zaopatrywała $\mathrm{W}$ nie wszystkie poradnie $\mathrm{w}$ okręgu. $\mathrm{Z}$ pomieszczeń administracyjnych istotne były też: sekretariat, poczekalnia z czytelnią dla rodziców i dzieci oraz archiwum. Zabiegi Dyrektora OPWZ Jana Wojtaszka ${ }^{23}$ w sprawie pozyskania nowego lokalu wspierało kuratorium, niestety bezskutecznie.

Znacznie lepsza od lokalowej, była sytuacja kadrowa w poradni okręgowej. Zatrudnienie $\mathrm{w}$ tej placówce nie odbiegało od wymogów określonych w kolejnych zarządzeniach Ministra Oświaty ${ }^{24}$, a w niektórych latach nawet je przekraczało.

Statut poradni z 1964 r. dopuszczał zatrudnianie w niej pracowników pedagogicznych, administracyjnych i obsługi. Do pracowników pedagogicznych zaliczono: kierowników poradni, nauczycieli-psychologów i instruktorów społecznych. Wśród pracowników administracji i obsługi wymieniono: sekretarzy, referentów, księgowych, woźnych i sprzątaczki. Zakres obowiązków na poszczególnych stanowiskach pracy ustalał kierownik poradni, natomiast jego obowiązki określono w statucie. Do niego należało: kierowanie działalnością pracowników i nadzorowanie wykonania przez nich ustalonych zadań; opracowywanie planów pracy, preliminarzy budżetowych i sprawozdań; dysponowanie środkami finansowymi poradni oraz zarządzanie użytkowanym majątkiem; reprezentowanie poradni; a poza tym bezpośredni udział w realizacji podstawowych zadań poradni.

W przepisach z 1968 r., wraz z wprowadzeniem podziału na poradnie okręgowe i powiatowe (miejskie, dzielnicowe), rozróżniono również stanowiska kierownicze. W poradni okręgowej zatrudniano od tej pory dyrektora, w pozostałych nadal kierownika. Zakres obowiązków na tych stanowiskach pozostał bez zmian, określono natomiast wymagane kwalifikacje. Zarówno dyrektor, jak i kierownik musieli posiadać ukończone studia wyższe i stopień naukowy co najmniej magistra w zakresie psychologii lub pedagogiki oraz przynajmniej pięcioletni staż pracy w poradni wychowawczo-zawodowej lub poradni zdrowia psychicznego.

Ponadto w nowym statucie zmieniono stanowisko instruktora społecznego na stanowisko nauczyciela. Określono także kwalifikacje i uprawnienia poszczególnych pracow-

23 Jan Wojtaszek został dyrektorem Okręgowej Poradni Wychowawczo-Zawodowej w Poznaniu w 1972 roku; źródła wywołane: wywiad z dn. 16.09.2008 r. z Janem Wojtaszkiem.

${ }^{24}$ Zarządzenie Ministra Oświaty z dnia 1 sierpnia 1964 r. w sprawie organizacji poradni wychowawczozawodowych (Dz. Urz. Min. Ośw. 1964, nr 10, poz. 108); Zarządzenie Ministra Oświaty i Szkolnictwa Wyższego z dnia 21 września 1968 r. w sprawie organizacji i działalności poradni wychowawczo-zawodowych (Dz. Urz. Min. Ośw. i Szkol. Wyż. 1968, nr B-12, poz. 102); Zarządzenie Ministra Oświaty i Wychowania z dnia 14 czerwca 1973 r. w sprawie organizacji i działalności poradni wychowawczo-zawodowych (Dz. Urz. MOiW 1973, nr 11, poz. 89). 
ników pedagogicznych. Nauczyciel-psycholog powinien posiadać studia wyższe w zakresie psychologii. Pracownik taki uprawniony był do prowadzenia wszystkich działów poradnictwa w placówce. Na stanowisku nauczyciela dopuszczono zatrudnianie osób o różnych kwalifikacjach, jednak uzależniono od nich zakres uprawnień. Nauczyciel posiadający studia wyższe w zakresie pedagogiki mógł prowadzić wszystkie działy poradnictwa z wyłączeniem psychologicznych badań diagnostycznych. Nauczyciel, który ukończył studium nauczycielskie mógł prowadzić w poszczególnych działach określone czynności: wywiady w sprawie dziecka w domu, szkole lub placówce oświatowo-wychowawczej, oddziaływanie pedagogiczne na środowisko, załatwianie spraw interwencyjnych itp. W przypadku innych kwalifikacji zakres obowiązków nauczyciela ustalał kierownik lub dyrektor poradni.

Wkrótce jednak podniesiono wymagania wobec kwalifikacji pracowników poradni, szczególnie okręgowej. Zgodnie ze statutem z 1973 r. wszyscy pracownicy pedagogiczni powinni posiadać wyższe studia magisterskie. Zamieniono etat nauczyciela na stanowisko pedagoga i postawiono wymagania wyższych studiów magisterskich w zakresie pedagogiki. W przypadku innych magisterskich studiów humanistycznych lub ekonomicznych miały być one uzupełnione specjalizacją przydatną do pracy w poradni i doświadczeniem w pracy wychowawczej. Ponadto psycholog zatrudniany w poradni okręgowej miał już posiadać przynajmniej dwuletni staż pracy w poradnictwie, a pedagog podobny staż pracy w szkole lub innej placówce oświatowo-wychowawczej ${ }^{25}$.

Istotną kwestią kadrową było określenie w statucie z 1968 r. minimalnej liczby pracowników pedagogicznych niezbędnych do realizacji zadań poradni. Minimum dla poradni okręgowej ustalono na siedmiu pracowników pedagogicznych, w tym czterech lub pięciu psychologów. Natomiast od roku 1973 kadra pedagogiczna poradni okręgowych powinna obejmować przynajmniej dziewięciu pracowników, w tym minimum czterech psychologów.

Odpowiedzialność za zapewnienie poradniom właściwej liczby wykwalifikowanych pracowników, a także odpowiednich warunków lokalowych i finansowych, umożliwiających prawidłową realizację zadań statutowych spoczywała na władzach administracji szkolnej ${ }^{26}$. A warunki te miały istotne znaczenie wobec stopniowego rozszerzania zakresu działalności poradnictwa wychowawczo-zawodowego. Kolejne przepisy oświatowe $\mathrm{w}$ pewnym stopniu sankcjonowały prace podejmowane $\mathrm{w}$ odpowiedzi na zapotrzebowanie systemu oświaty, ale także wyznaczały nowe kierunki, nie wykreślając dotychczasowych. W statucie z 1973 r. zawarto bardzo długą listę zadań w obszarach: poradnictwa wychowawczego, orientacji szkolnej i orientacji zawodowej. Ponadto poradnie przejęły od likwidowanych ośrodków selekcyjnych zadanie diagnozy i kwalifikacji dzieci upośle-

${ }^{25}$ Załącznik do zarządzenia Ministra Oświaty i Wychowania z dnia 14 czerwca 1973r., Statut poradni wychowawczo-zawodowej..., III Pracownicy, ust. 6, 7.

${ }^{26}$ Zarządzenie Ministra Oświaty i Wychowania z dnia 14 czerwca 1973r. w sprawie organizacji i działalności poradni wychowawczo-zawodowych..., § 6 i $§ 7$. 
dzonych umysłowo do kształcenia specjalnego, przez co zostały włączone w kształtujący się właśnie system kształcenia specjalnego i opieki nad dzieckiem upośledzonym ${ }^{27}$.

Okręgowa Poradnia Wychowawczo-Zawodowa w Poznaniu poza realizacją zadań diagnostycznych, postdiagnostycznych i profilaktycznych, przypisanych wszystkim poradniom, prowadziła również działalność dodatkową wynikającą z jej koordynacyjnej funkcji. Do jej zadań statutowych należało bowiem opracowywanie materiałów metodycznych, współorganizacja i pomoc w szkoleniach nauczycieli, doskonalenie kadry poradni terenowych, prowadzenie prac badawczych nad formami i metodami poradnictwa wychowawczo-zawodowego ${ }^{28}$.

OPWZ w Poznaniu ściśle współpracowała z Instytutami Pedagogiki i Psychologii UAM w zakresie doskonalenia kadr, wydawnictw metodycznych, standaryzacji testów, inicjatyw organizacyjnych, a nawet wymiany pracowników. Z Instytutem Psychologii związany był pierwszy kierownik poradni prof. dr Bolesław Hornowski. Z kolei w 1972 r. do pracy w instytucie przeszła dyrektor poradni okręgowej dr Barbara Rosemann. Wówczas zastąpił ją mgr Jan Wojtaszek. W różnych okresach z poradnią powiązani byli zawodowo także pracownicy instytutów UAM: dr Zenon Krążyński i dr Adam Czoperski. Wspólne inicjatywy realizowano także z prof. dr hab. Marią Tyszkową, prof. dr hab. Stanisławem Szajkiem, doc. dr hab. Benonem Bromberkiem oraz innymi pracownikami naukowymi $\mathrm{i}$ instytucjami ${ }^{29}$.

Wyrazem tej współpracy było m. in. rozpoczęcie w 1973 r. działalności wydawniczej. Od tego roku zaczął ukazywać się biuletyn OPWZ „Problematyka Poradnictwa Wychowawczego oraz Orientacji Szkolnej i Zawodowej”30 pod redakcją prof. S. Szajka. W 1974 r. zapoczątkowano, również pod jego redakcją, publikację serii zeszytów Orientacja szkolna i zawodowa w procesie nauczania. Materiały pomocnicze dla nauczycieli ${ }^{31}$. Rok później wydano siedem części z serii Osobowość i funkcjonowanie spoleczne uczniów zdol-

27 Zob. J. Wojtaszek, System poradnictwa wychowawczego oraz preorientacji szkolnej i zawodowej na tle aktualnych problemów szkolnictwa Wielkopolski, „Problematyka Poradnictwa Wychowawczego oraz Orientacji Szkolnej i Zawodowej” 1973, nr 1, s. 15-18.

${ }_{28}$ Zob. Załącznik do zarządzenia Ministra Oświaty i Szkolnictwa Wyższego z dnia 21 września 1968 r., Statut poradni wychowawczo-zawodowej..., I, ust. 3, pkt a-g; Załącznik do zarządzenia Ministra Oświaty $i$ Wychowania z dnia 14 czerwca 1973r., Statut poradni wychowawczo-zawodowej..., II, ust. 5, pkt 1-5.

29 Źródła wywołane: wywiad z dn. 16.09.2008 r. z Janem Wojtaszkiem...

${ }^{30}$ W 1973 r. ukazały się dwa numery, a od 1974 r. biuletyn wychodził jako rocznik aż do 1989 r.

31 Do roku 1975 wydano siedem z ośmiu zeszytów: S. Szajek, Orientacja szkolna i zawodowa w procesie nauczania, Poznań 1974; I. Lisiak, Wykorzystanie procesu nauczania wychowania obywatelskiego dla przygotowania uczniów do wyboru zawodu, Poznań 1974; K. Konieczna, Wykorzystanie lekcji biologii dla przygotowania uczniów szkół podstawowych do wyboru zawodu, Poznań 1974; A. Kosior, Zwiazek nauczania matematyki w szkole podstawowej z przygotowaniem uczniów do wyboru zawodu, Poznań 1974; M. Józefiak, Wykorzystanie lekcji fizyki dla przygotowania uczniów do wyboru zawodu, Poznań 1974; D. Staniszewska, Wykorzystanie treści i procesu nauczania chemii dla przygotowania uczniów szkót podstawowych do wyboru zawodu, Poznań 1974; A. Smykowski, Rola zajęć praktyczno-technicznych w przygotowaniu uczniów szkół podstawowych do świadomego wyboru zawodu i szkoty, Poznań 1975; L. Moryniak, Wykorzystanie treści i procesu nauczania geografii dla przygotowania uczniów szkót podstawowych do wyboru zawodu i szkoły. Materiaty pomocnicze dla nauczycieli geografii, Poznań 1976. 
nych pod redakcją prof. M. Tyszkowej ${ }^{32}$. Poza wydawnictwami ciągłymi OPWZ publikowała szereg innych materiałów przydatnych nauczycielom i pracownikom poradni w pracy związanej z zagadnieniami dojrzałości szkolnej, orientacji zawodowej i szkolnej, profilaktyki, reedukacji, logopedii itp. ${ }^{33}$ Do użytku poradni terenowych przygotowano i opublikowano narzędzia diagnostyczne: Kwestionariusz artykulacyjny do ustalania wad wymowy u dzieci nieczytających oraz u dzieci czytajacych dr Teresy Bartkowskiej oraz Test czytania i pisania dla klas I-III szkoty podstawowej Teresy Straburzyńskiej. Pracownicy poradni podejmowali także działalność publicystyczną na łamach różnych czasopism, np. „Twoje Dziecko”, „Głos Kobiety”, „Nurt”, „Zbiorcza Szkoła Gminna”, „Szkoła Specjalna”, „Życie Szkoły”, „Z doświadczeń nauczycieli wielkopolskich”, „Głos Wielkopolski”, „Gazeta Poznańska” i wiele innych.

Drugim bardzo ważnym kierunkiem pracy OPWZ w Poznaniu była działalność szkoleniowa, szczególnie rozwinięta w latach 70. Przykładowo: w dniach 11-20 grudnia 1972 r. zorganizowano w Poznaniu kurs dla dyrektorów i pracowników poradni, w którym wzięły udział 104 osoby. Przedstawiono na nim baterię nowych testów do stosowania w poradnictwie oraz ujednolicono badania dojrzałości szkolnej i stosowanie testów wiadomości szkolnych w poznańskim okręgu szkolnym. W 1973 r. rozpoczęto szkolenia dotyczące zespołów reedukacyjnych. OPWZ zorganizowała kilkudniowe szkolenie dla pedagogów poradni (25-28 kwietnia 1973 r.) oraz dwutygodniowe dla nauczycieli klas I-IV ze zbiorczych szkół gminnych (26 czerwca -7 lipca 1973 r.). W 1974 r. kursy dla nauczycieli reedukatorów ukończyło ponad 700 osób w 15 powiatach. Ponadto we współpracy z Instytutem Kształcenia Nauczycieli i Badań Oświatowych (IKNiBO) poradnia okręgowa uruchomiła roczne Studium Logopedyczne. W pierwszym roku (1973/1974 r.) ukończyło je 66 pracowników poradni i nauczycieli szkół.

Szkolenia organizowano również poza Poznaniem. W 1974 r. odbył się kurs w Kaliszu dla pracowników wszystkich poradni terenowych (fot. 2). Poruszono na nim zagadnienia orzecznictwa i kwalifikacji, zasady rozpoznawania niedostosowania społecznego, przydatność nowych testów w poradnictwie i inne.

32 Zob. M. Tyszkowa, Zdolności i osobowość ucznia a jego funkcjonowanie w szkole, Poznań 1975; D. Nastrosza, Procesy myślowe u uczniów uzdolnionych do matematyki i przeciętnych $w$ toku rozwiąywania trudnych zadań, Poznań 1975; H. Smerda, Cechy osobowości młodzieży wybitnie uzdolnionej matematycznie, Poznań 1975; Ch. Zeler, Cechy osobowości młodzieży wybitnie uzdolnionej do języków obcych, Poznań 1975; K. Poręba, Obraz siebie i samoocena młodzieży uzdolnionej artystycznie, Poznań 1975; M. Główka, Stosunki społeczne w klasach młodzieży wybitnie uzdolnionej, Poznań 1975; M. Gątkowska, Charakterystyczne cechy osobowości uczniów bardzo dobrych, Poznań 1975.

33 Zob. Wytyczne do planowania pracy w zakresie przygotowania uczniów klas V-VIII do wyboru kierunku dalszego kształcenia i zawodu, Poznań 1973; Wytyczne do organizowania klas oraz grup reedukacyjnych w zbiorczych szkołach gminnych, Poznań 1973; Informator dla kandydatów do szkót ponadpodstawowych miasta Poznania i województwa poznańskiego na rok szkolny 1974/75, Poznań 1974; M. Korde, Wytyczne do ćwiczeń rozwijajacych dojrzałość szkolna dziecka dla nauczycieli przedszkoli i ognisk przedszkolnych, Poznań 1974; J. Szambelan, Orientacja szkolna i zawodowa. Informacja bibliograficzna, Poznań 1974; Szkoly gminne w Polsce a poradnictwo wychowawczo-zawodowe, Poznań 1974; Reedukacja dzieci z trudnościami w czytaniu i pisaniu. Materiały pomocnicze dla nauczyciela, Poznań 1975. 


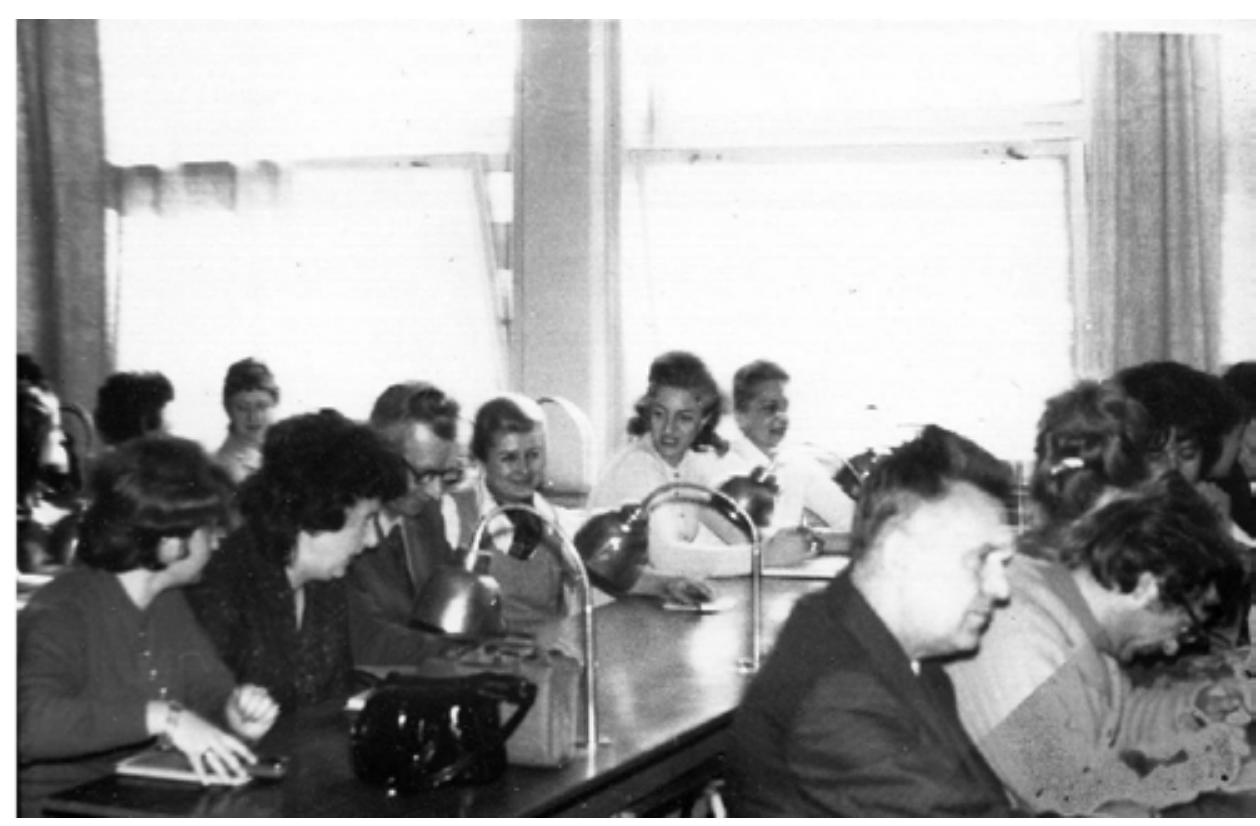

Fot. 2. Kurs dla pracowników poradni wychowawczo-zawodowych, zorganizowany $\mathrm{w}$ dn. 7-11.04.1974 r. w Kaliszu przez IKNiBO i OPWZ w Poznaniu

Źródło: Kronika Poradni Wychowawczo-Zawodowej w Kaliszu, AZ PPP nr 1 w Kaliszu.

Poza tym poradnia okręgowa przygotowywała spotkania o zasięgu ogólnopolskim. W dniach 3-4 kwietnia 1974 r. w Poznaniu odbyła się Ogólnopolska Narada Dyrektorów Poradni Okręgowych z udziałem przedstawiciela Ministerstwa Oświaty i Wychowania. Eksperci z Ministerstwa wzięli udział również w seminarium naukowym przygotowanym 12 maja 1975 r. nt. „Pomocy dzieciom z odchyleniami i zaburzeniami rozwojowymi”. Referaty wygłosili na nim także pracownicy poradni (np. Jarosława Radzicka, Bożena Eckardt, Jan Wojtaszek) oraz pracownicy nauki (prof. dr hab. Maria Tyszkowa, dr hab. med. Tadeusz Wróblewski) ${ }^{34}$.

W 1974 r. utworzono, przy dużej pomocy Instytutu Pedagogiki UAM, pierwszy w Polsce Gabinet Orientacji i Poradnictwa Zawodowego. Miał on zarówno wspierać działalność poradni terenowych i szkół, jak i prowadzić bezpośrednią działalność na rzecz dzieci i młodzieży ${ }^{35}$. Już w pierwszym roku istnienia przeprowadzono lekcje zawodoznawcze dla ponad 4 tys. uczniów. Zorganizowano także ekspozycje zawodów budowlanych i rolniczych, z uwagi na takie zapotrzebowanie społeczne ${ }^{36}$. Rok później -

34 J. Wojtaszek, Kalendarium ważniejszych wydarzeń w poradnictwie wychowawczo-zawodowym woj. poznańskiego w latach 1972-1985, „Problematyka Poradnictwa Wychowawczego oraz Orientacji Szkolnej i Zawodowej 1986, nr 12, s. 113-115.

35 S. Szajek, Orientacja i poradnictwo zawodowe, Warszawa 1979, s. 35.

36 J. Wojtaszek, Kalendarium..., s. 114. 
w czerwcu 1975 r. podpisano umowę z Instytutem Psychologii UAM w sprawie organizacji Pracowni Psychologii Szkolnej. Miała ona pełnić funkcje naukowo-badawcze o charakterze innowacyjno-wdrożeniowym oraz sprawować opiekę psychologiczną nad uczniami Szkoły Podstawowej Nr 30 w Poznaniu ${ }^{37}$.

Działalność Okręgowej Poradni Wychowawczo-Zawodowej, podejmowane przez nią inicjatywy sprawiły, że dzięki wypracowanej pozycji wywierała ona wpływ na rozwój poradnictwa wychowawczo-zawodowego także poza granicami województwa. Prof. Stanisław Szajek z UAM w Poznaniu wyraził się na jej temat, że „swą inspirującą, koordynującą i organizacyjną działalnością zda się przodować” zarówno w województwie, jak i w kraju ${ }^{38}$.

\section{Wojewódzka Poradnia Wychowawczo-Zawodowa (1975-1993)}

W połowie roku 1975 dokonano nowego podziału administracyjnego kraju ${ }^{39}$. Do zmian wynikających z reformy administracyjnej dostosowano również system poradnictwa wychowawczo-zawodowego. W każdym województwie stworzono odrębną strukturę. W okrojonym nowym poznańskim rolę poradni wojewódzkiej przejęła oczywiście była poradnia okręgowa pod kierownictwem Jana Wojtaszka ${ }^{40}$.

Dyrektor Wojewódzkiej Poradni Wychowawczo-Zawodowej (WPWZ), upoważniony przez Kuratora Oświaty i Wychowania w Poznaniu, nadzorował całokształt spraw związanych z poradnictwem wychowawczo-zawodowym w województwie. To on podejmował więc decyzje o kształcie sieci poradnictwa w województwie, wydawał poszczególnym placówkom orzeczenia organizacyjne, ustalał zakres ich działania, a także powoływał filie przy istniejących już placówkach ${ }^{41}$. Do roku 1989 w ramach tworzonej i nadzorowanej przez niego sieci funkcjonowało: 1 poradnia wojewódzka, 7 poradni poznańskich, 12 miejsko-gminnych poradni terenowych, 6 filii oraz 2 wydzielone jednostki o specyficznym zakresie pracy: Gabinet Orientacji Zawodowej i Pracownia Psychologii Szkolnej (tab. 2).

37 J. Wojtaszek, Pracownia Psychologii Szkolnej [w:] Materiaty - Informacje - Sprawozdania Regionalnej Izby Pamiątek Oświatowych, z. 7, Poznań 1990, s. 33.

38 S. Szajek, Orientacja i poradnictwo..., s. 35.

39 Ustawa z dnia 28 maja 1975 r. o dwustopniowym podziale administracyjnym Państwa oraz o zmianie ustawy o radach narodowych (Dz. U. 1975, nr 16, poz. 91).

${ }^{40}$ Zarządzenie Kuratora Oświaty i wychowania w Poznaniu z dnia 05.08.1975 r. w sprawie zakresu działania Wojewódzkiej Poradni Wychowawczo-Zawodowej, AZ PPP-S w Poznaniu.

${ }^{41}$ Ibidem; Okólnik Dyrektora Wojewódzkiej Poradni Wychowawczo-Zawodowej w Poznaniu z dnia 15. VIII.1975 r. w sprawie zasięgu działania miejskich i gminnych poradni wychowawczo-zawodowych, AZ PPP -S w Poznaniu. 
Tabela 2. Sieć poradnictwa wychowawczo-zawodowego na terenie woj. poznańskiego (wg stanu na rok 1988)

\begin{tabular}{|c|c|c|c|c|c|}
\hline Lp. & $\begin{array}{c}\text { Poradnia } \\
\text { (nazwa, adres, filie) }\end{array}$ & $\begin{array}{c}\text { Rok } \\
\text { założenia }\end{array}$ & Lp. & $\begin{array}{c}\text { Poradnia } \\
\text { (nazwa, adres, filie) }\end{array}$ & $\begin{array}{c}\text { Rok } \\
\text { założe- } \\
\text { nia }\end{array}$ \\
\hline \multirow[t]{3}{*}{1} & \multirow{3}{*}{$\begin{array}{l}\text { Wojewódzka PWZ w Poznaniu } \\
\text { ul. } 27 \text { Grudnia } 19 \\
\text { + filia w Tarnowie Podgórnym } \\
\text { + Gabinet Orientacji i Poradnictwa } \\
\text { Zawodowego } \\
\text { + Pracownia Psychologii Szkolnej } \\
\text { + filia w Kórniku }\end{array}$} & \multirow{3}{*}{$\begin{array}{l}1957 \\
1974 \\
1974 \\
1975 \\
1981\end{array}$} & 10 & $\begin{array}{l}\text { PWZ w Nowym Tomyślu } \\
\text { Plac XX-lecia PRL 4a }\end{array}$ & 1967 \\
\hline & & & 11 & $\begin{array}{l}\text { PWZ we Wrześni } \\
\text { ul. Konopnickiej 20a }\end{array}$ & 1970 \\
\hline & & & 12 & $\begin{array}{l}\text { PWZ w Obornikach } \\
\text { ul. Mickiewicza } 2\end{array}$ & 1972 \\
\hline 2 & $\begin{array}{l}\text { PWZ w Gnieźnie } \\
\text { ul. Chrobrego } 41\end{array}$ & 1958 & 13 & $\begin{array}{l}\text { PWZ Poznań-Górczyn } \\
\text { ul. Siemiradzkiego } 11 \\
\text { + filia w Czerwonaku }\end{array}$ & $\begin{array}{l}1973 \\
1977\end{array}$ \\
\hline 3 & $\begin{array}{l}\text { PWZ w Środzie Wlkp. } \\
\text { ul. } 20 \text { Października } 68 \\
\text { + filia w Krzykosach }\end{array}$ & $\begin{array}{l}1960 \\
1978\end{array}$ & 14 & $\begin{array}{l}\text { PWZ w Szamotułach } \\
\text { ul. Staszica } 1 \\
\text { + filia w Pniewach }\end{array}$ & $\begin{array}{l}1973 \\
1985\end{array}$ \\
\hline 4 & $\begin{array}{l}\text { PWZ Poznań-Stare Miasto } \\
\text { ul. Ratajczaka 1a }\end{array}$ & 1961 & 15 & $\begin{array}{l}\text { PWZ w Kłecku } \\
\text { ul. Gnieźnieńska } 9\end{array}$ & 1975 \\
\hline 5 & $\begin{array}{l}\text { PWZ Poznań-Grunwald } \\
\text { ul. Zakręt } 8 \\
\text { + filia w Dopiewie }\end{array}$ & $\begin{array}{l}1965 \\
1976\end{array}$ & 16 & $\begin{array}{l}\text { PWZ w Swarzędzu } \\
\text { ul. Polna } 21 \\
\text { + filia w Pobiedziskach }\end{array}$ & $\begin{array}{l}1975 \\
1977\end{array}$ \\
\hline 6 & $\begin{array}{l}\text { PWZ Poznań-Wilda } \\
\text { ul. Łozowa } 77\end{array}$ & 1965 & 17 & $\begin{array}{l}\text { PWZ w Mosinie } \\
\text { ul. Topolowa } 2\end{array}$ & 1975 \\
\hline 7 & $\begin{array}{l}\text { PWZ Poznań-Jeżyce } \\
\text { ul. Dąbrowskiego } 34\end{array}$ & 1966 & 18 & $\begin{array}{l}\text { PWZ w Luboniu } \\
\text { ul. Żabikowska } 40\end{array}$ & 1977 \\
\hline 8 & $\begin{array}{l}\text { PWZ Poznań-Nowe Miasto } \\
\text { ul. Antoniego } 42\end{array}$ & 1966 & 19 & $\begin{array}{l}\text { PWZ w Grodzisku Wlkp. } \\
\text { ul. } 3 \text { Maja } 5\end{array}$ & 1977 \\
\hline 9 & $\begin{array}{l}\text { PWZ w Śremie } \\
\text { ul. Kilińskiego } 9\end{array}$ & 1967 & 20 & $\begin{array}{l}\text { PWZ Poznań-Piątkowo } \\
\text { ul. Obornicka } 314\end{array}$ & 1988 \\
\hline
\end{tabular}

Źródło: Opracowanie własne na podstawie: Zanim podejmiesz decyzję o wyborze zawodu i pracy-przeczytaj! Poznań 1984, a także materiałów archiwalnych i źródeł wywołanych.

Zmiany administracyjne oraz organizacyjne wpłynęły między innymi na uporządkowanie struktury poradnictwa. Wiązały się z tym: lepszy przepływ informacji, jasne wytyczne i instrukcje, szeroki zakres szkoleń dla kadry pedagogicznej. Na szczeblu centralnym Ministerstwo Oświaty i Wychowania konstruowało akty prawne i wytyczne w sferze organizacyjno-prawnej, a w sferze merytorycznej zalecenia formułował Centralny Ośrodek Metodyczny Poradnictwa Wychowawczo-Zawodowego w Warszawie. Następnie były przekazywane poprzez poradnie wojewódzkie do poradni terenowych. Natomiast informacje sprawozdawcze, postulaty, potrzeby przechodziły drogę w przeciwnym kierunku - od poradni terenowych, opracowywane zbiorczo przez poradnie wojewódzkie, do ośrodka metodycznego lub bezpośrednio do Ministerstwa. 
Działalność WPWZ aż do roku 1993, niezmiennie opierała się głównie na wytycznych statutu z 1973 r. Podstawowymi kierunkami działalności były: poradnictwo wychowawcze oraz orientacja i poradnictwo zawodowe. Natomiast szczegółowy zakres zadań i form ich realizacji stopniowo był rozszerzany. Poradnia wojewódzka niezmiennie sprawowała nadzór merytoryczny nad realizacją zadań przez placówki terenowe. Ponadto prowadziła działalność szkoleniową, wydawniczą oraz innowacyjno-badawczą.

WPWZ w Poznaniu wyróżniała się pod względem liczby opracowań metodycznych i szkoleń o szerokiej tematyce, w tym z zakresu diagnostyki, orzecznictwa i kwalifikowania. Jej pracownicy opracowali narzędzia diagnostyczne ${ }^{42}$, które zostały upowszechnione nie tylko w poradniach województwa poznańskiego, ale w całym kraju. Do użytku zespołów orzekających publikowano także opracowania, wytyczne, wskazówki mające ujednolicić pracę $\mathrm{w}$ całym województwie oraz różne wzory druków ${ }^{43}$. Liczne publikacje autorstwa pracowników poradni ukazywały się także w biuletynie „Problematyka Poradnictwa Wychowawczego oraz Orientacji Szkolnej i Zawodowej”44.

WPWZ w Poznaniu organizowała również liczne spotkania, szkolenia, seminaria związane z problematyką diagnozy psychologicznej i pedagogicznej, w których uczestniczyli pracownicy poradni wychowawczo-zawodowych, pedagodzy szkolni, nauczyciele, pracownicy nauki i inni pracownicy oświaty. Wśród nich najbardziej znaczące to:

- seminarium szkoleniowe dla psychologów poradni, zorganizowane we współpracy z UAM, dotyczące metod psychologicznej diagnozy wczesnoszkolnych zaburzeń rozwojowych oraz zasad interpretowania wyników badań (25-27 marca 1976 r., Poznań),

- seminarium dla pedagogów poradni i szkół na temat diagnozy pedagogicznej i doskonalenia edukacji w nauczaniu początkowym (6-7 grudnia 1977 r., Poznań),

- wyjazdowa konferencja szkoleniowa pracowników poradni wychowawczo-zawodowych obejmująca problematykę orzecznictwa wychowawczego, styl kierowania i postęp pedagogiczny w poradnictwie (1979 r., Zielona Góra),

\footnotetext{
${ }^{42}$ Test do badania pedagogicznego dzieci 6-7 letnich z instrukcją, oprac. B. Eckardt, Z. Janiak, U. Wiśniewska, WPWZ w Poznaniu, Poznań 1977; Test pedagogiczny do badania dzieci 6-7 letnich, oprac. B. Eckardt, Z. Janiak, U. Wiśniewska, WPWZ w Poznaniu, Poznań 1981; Z. Krążyński, Testy wiadomości i umiejętności matematycznych dla klas I, II i III dziesięcioletniej szkoty średniej, Poznań 1979; Z. Krążyński, Testy wiadomości i umiejętności matematycznych dla klas I, II i III szkoły podstawowej, Warszawa 1986, Pedagogiczna metoda badania umiejętności czytania i pisania dla klas I-III szkoły podstawowej, oprac. T. Straburzyńska, T. Śliwińska, WPWZ w Poznaniu, Poznań 1980.

${ }^{43}$ Zob. Działalność orzeczniczo-kwalifikacyjna poradni wychowawczo-zawodowych, oprac. J. Radzicka, KOiW, WPWZ w Poznaniu, Poznań 1975; Zadania poradni wychowawczo-zawodowych i placówek oświatowo-wychowawczych $w$ zakresie profilaktyki i resocjalizacji społecznego niedostosowania, oprac. J. Radzicka, WPWZ w Poznaniu, Poznań 1975; A. Brzezińska, Zasady psychologiczno-pedagogicznego badania dzieci w wieku przedszkolnym. Poradnik zawodowy, WPWZ w Poznaniu, Poznań 1985; M. Pietkiewicz, S. Szajek, Wytyczne Wojewódzkiej Poradni Wychowawczo-Zawodowej do planowania pracy w zakresie orientacji i poradnictwa zawodowego $w$ liceum ogólnokształcacym (1976, nr 5); U. Niesiołowska, Wybór zawodu a sprawność narzadów somatycznych (1977, nr 6; 1978, nr 7; 1979, nr 8; 1980, nr 9); M. Kurzawa, Propozycje wytycznych do opracowania monografii wychowawczej szkoty dla pedagogów szkolnych i pracowników poradni wychowawczo-zawodowych (1980, nr 9); R. Gąsiorek, U. Niesiołowska, Zasady wydawania zaświadczeń w sprawie specjalnego kształcenia zawodowego (1982, nr 10) i inne.

${ }^{44}$ Por. „Problematyka Poradnictwa Wychowawczego oraz Orientacji Szkolnej i Zawodowej”, 1973-1989, nr $1-13$.
} 
- seminarium dla pracowników poradni i pedagogów szkolnych, zorganizowane we współpracy z UAM, dotyczące sposobów diagnozowania stosunków społecznych uczniów z objawami niedostosowania społecznego (22 maja 1981 r., Poznań),

- seminarium dla pracowników poradni na temat oceny gotowości dziecka do podjęcia nauki w klasie pierwszej szkoły podstawowej; problematykę przybliżyli dr Anna Brzezińska i dr Zenon Krążyński z Instytutu Psychologii UAM (1982 r., Poznań),

- seminarium dla pracowników poradni poświęcone wybranym problemom diagnozy i terapii psychologicznej i pedagogicznej oraz indywidualnej i grupowej pomocy dzieciom i młodzieży (4-6 czerwca 1984 r., Zaniemyśl $)^{45}$.

Pracownicy WPWZ w Poznaniu prowadzili lub współorganizowali także studia podyplomowe ${ }^{46}$. Kontynuowano pracę Studium Logopedycznego, powołanego przez WPWZ i IKNiBO w Poznaniu jeszcze w 1973 r. We współpracy z IKNiBO uruchomiono w 1976 r. Studium Orientacji i Poradnictwa Zawodowego. Niemal jednocześnie, bo od 1977 r., z inicjatywy WPWZ w Poznaniu powstało Podyplomowe Studium Orientacji i Poradnictwa Zawodowego w Instytucie Pedagogiki UAM. Natomiast w 1983 r., także za namową pracowników WPWZ w Poznaniu, doc. dr hab. Helena Sęk opracowała koncepcję i uruchomiła w ramach Instytutu Psychologii UAM studia podyplomowe pod nazwą „Psychoprofilaktyka, diagnoza i elementy psychoterapii w poradnictwie psychologicznym" ${ }^{\prime 4}$. Ponadto pracownicy poradni wojewódzkiej prowadzili zajęcia teoretyczne i praktyczne w Policealnym Studium Wychowania Przedszkolnego ${ }^{48}$.

W ramach poznańskiej poradni wojewódzkiej funkcjonował, wspomniany już, Gabinet Orientacji i Poradnictwa Zawodowego. Początkowo zlokalizowano go w czterech pomieszczeniach jednej ze szkół przy ul. Stalingradzkiej 43 w Poznaniu. W latach 80 . został przeniesiony do lokalu przy ul. Nowowiejskiego 29, cały czas stanowił jednak integralną część WPWZ ${ }^{49}$. Wyodrębniono w nim cztery działy: szkolnictwa ponadpodstawowego, szkolnictwa policealnego i wyższego, pokój konsultacyjno-instruktażowy, pracownię psychotechniczną; według projektu prof. S. Szajka ${ }^{50}$.

Pracownicy pedagogiczni gabinetu organizowali wykłady, pogadanki, spotkania z przedstawicielami różnych zawodów i instytucji, wystawy, ekspozycje zawodów, poka-

45 J. Wojtaszek, Kalendarium ważniejszych wydarzeń w poradnictwie wychowawczo-zawodowym woj. poznańskiego w latach 1972-1985, „Problematyka Poradnictwa Wychowawczego oraz Orientacji Szkolnej i Zawodowej" 1986, nr 12, s. 116-123.

${ }^{46}$ Ibidem, s. 117, 120, 123; a także źródła wywołane: wywiad z dnia 16.09.2008 r. z Janem Wojtaszkiem - dyrektorem Okręgowej (później Wojewódzkiej) Poradni Wychowawczo-Zawodowej w Poznaniu.

47 Zob. Program studiów podyplomowych „, Psychoprofilaktyka, diagnoza i elementy psychoterapii w poradnictwie psychologicznym”, red. Sęk H., Uniwersytet im. Adama Mickiewicza Instytut Psychologii, Wojewódzka Poradnia Wychowawczo-Zawodowa w Poznaniu, Poznań 1983.

${ }^{48}$ Aneks do sprawozdania statystycznego GUS za rok szkolny 1980/81 [WPWZ w Poznaniu], AZ PPP-S w Poznaniu.

49 Chcesz wybrać zawód - szkołę - pracę? Przeczytaj, Poznań 1977, s. 44; Zanim podejmiesz decyzję o wyborze zawodu i pracy poczytaj, Urząd Wojewódzki w Poznaniu Wydział Zatrudnienia i Spraw Socjalnych, Wojewódzka Poradnia Wychowawczo-Zawodowa w Poznaniu, Poznań 1984, s. 74.

${ }^{50}$ Por. S. Szajek, Problemy zawodoznawcze w szkole podstawowej, w: Psychologiczne i pedagogiczne problemy poradnictwa zawodowego, Warszawa 1975. 
zy filmów, wycieczki zawodoznawcze i wiele innych. Uczniowie, rodzice i nauczyciele mieli bezpośredni dostęp do porad i konsultacji doradców zawodowych. Na terenie gabinetu odbywały się także zajęcia szkoleniowe dla słuchaczy kursów i studiów podyplomowych z zakresu orientacji i poradnictwa zawodowego, staże studenckie, szkolenia nauczycieli i dyrektorów szkół. Od kwietnia do lipca każdego roku lokalizowano w nim Wojewódzki Punkt Informacji Zawodowej, który gromadził i udostępniał aktualne informacje o szkołach, wolnych miejscach i wynikach rekrutacji ${ }^{51}$.

W oparciu o poznański model gabinetu orientacji i poradnictwa zawodowego uruchamiano podobne w poradniach wychowawczo-zawodowych i szkołach na terenie województwa. Stał się on także wzorem powielanym w innych województwach w kraju.

Ewenementem - zarówno na skalę regionu Wielkopolski, jak i całego kraju - była także Pracownia Psychologii Szkolnej. Funkcjonowała zgodnie z umową przez okres dziesięciu lat, tj. w latach 1975-1985. Podstawowym terenem działalności była Szkoła Podstawowa nr $30 \mathrm{w}$ Poznaniu, w której pomieszczeniach zlokalizowano pracownię. Głównymi inicjatorami i organizatorami działań byli: prof. dr hab. Maria Tyszkowa (kierownik Zakładu Psychologii Rozwojowej i Wychowawczej), dr Zenon Krążyński (adiunkt we wspomnianym zakładzie, kierownik nowopowstałej pracowni), Barbara Łukasiak (psycholog WPWZ), Maria Wojtaszek (dyrektor Szkoły Podstawowej nr 30) i Jan Wojtaszek (dyrektor WPWZ). Z pracownią blisko współpracowały także: Ewa Mętkowska (pedagog Szkoły Podstawowej nr 30) oraz Jarosława Radzicka (zastępca dyrektora WPWZ w Poznaniu) ${ }^{52}$.

Zadania realizowane przez kadrę pracowni na terenie Szkoły Podstawowej nr 30 łączyły działalność teoretyczną i praktyczną. Prowadzono w niej prace badawcze wynikające z planu naukowo-badawczego Zakładu Psychologii Rozwojowej i Wychowawczej Instytutu Psychologii UAM, np.: odporność psychiczna dzieci; rozwój i funkcjonowanie dzieci z rodzin defektywnych; stosunki społeczne w grupach dzieci w różnym wieku; motywy uczenia się i negatywne postawy wobec niektórych przedmiotów szkolnych; przyczyny trudności w uczeniu się matematyki u uczniów klas I-IV; przyczyny trudności w rozwiązywaniu zadań matematycznych, występujące w starszych klasach szkoły podstawowej; przyczyny trudności w nauce czytania i pisania ${ }^{53}$. Jednocześnie Kuratorium Oświaty w Poznaniu nadało szkole, w której mieściła się pracownia, status szkoły ćwiczeń. Dzięki temu studenci psychologii o specjalizacji w zakresie psychologii wychowawczej mogli w ramach ćwiczeń lub praktyk uczestniczyć w realnym procesie dydaktyczno-wychowawczym.

51 Zob. J. Paruszewska-Gołębiewska, G. Tadeusiewicz, J. Wojtaszek, Gabinet zawodoznawczy, w: Orientacja i poradnictwo zawodowe w szkole podstawowej, red. W. Rachalska, Warszawa 1980, s. 149-160.

52 J. Wojtaszek, Pracownia Psychologii Szkolnej, w: Materiały - Informacje - Sprawozdania Regionalnej Izby Pamiątek Oświatowych, z. 7, Poznań 1990, s. 33-35; źródła wywołane: wywiad z dn. 16 września 2008 r. z Janem Wojtaszkiem...

${ }^{53}$ H. Gawrońska, Sprawozdanie z zebrania kolektywu kierowniczego i personelu Pracowni Psychologii Szkolnej, w: Psychologiczno-wychowawcze problemy szkoły. Materiaty i sprawozdania Pracowni Psychologii Szkolnej przy Szkole Podstawowej Nr 30, red. M. Tyszkowa, z. 1, Poznań 1977, s. 63-64. 
Drugi kierunek działalności pracowni zakładał wypracowanie modelu opieki psychologicznej w szkole, prowadzono więc prace usługowe zgodnie z potrzebami Szkoły Podstawowej nr 30. Prace te obejmowały w szczególności: badania diagnostyczne i działalność psychoterapeutyczną, pomoc i kierowanie pracą zespołów reedukacyjnych, nadzór nad poszerzonymi zapisami do klasy I, poradnictwo zawodowe i preorientacja, dokształcanie psychologiczne nauczycieli, pedagogizację i poradnictwo dla rodziców ${ }^{54}$.

O wynikach prac badawczych oraz działalności praktycznej informowano między innymi w serii publikacji pt. Psychologiczno-wychowawcze problemy szkoty ${ }^{55}$ oraz w biuletynie WPWZ w Poznaniu. Z doświadczeń pracowni mogły więc korzystać wszystkie poradnie wychowawczo-zawodowe.

Pracownicy WPWZ w Poznaniu podejmowali również szereg działań pozastatutowych, m. in. brali udział w nagraniach audycji w Polskim Radio, w dyskusyjnym forum „Głosu Wielkopolskiego” oraz obsługiwali Telefoniczną Informację Zawodową (także w redakcji „Głosu Wielkopolskiego”). Prowadzili też nabór do klasy zerowej w Ośrodku Szkolno-Wychowawczym dla Dzieci Głuchych w Poznaniu, wnioskowali do kuratorium i doprowadzili do utworzenia w szkole podstawowej oddziałów dla dzieci niedosłyszą$\mathrm{cych}^{56}$.

W 1989 r. działalność poradni wojewódzkiej w Poznaniu została ograniczona przez przemiany ustrojowe w kraju, a co za tym idzie zmiany we wszystkich dziedzinach życia. Podjęto również polemikę nad instytucją poradni wychowawczo-zawodowej. Poddano W wątpliwość adekwatność nazwy do realizowanych celów, a obowiązujący od 1975 r. statut uznano za hamujący lub uniemożliwiający nowe inicjatywy i prace. Wkrótce poradnie wojewódzkie, w tym poznańska, straciły na znaczeniu, wraz z ograniczeniem ich wiodącej i koordynującej roli w poszczególnych województwach.

\section{Ośrodek Diagnostyki i Terapii Psychologiczno-Pedagogicznej dla Dzieci i Młodzieży Niepełnosprawnej (1993-1996)}

Z dniem 20 września 1993 r. poradnie wychowawczo-zawodowe województwa poznańskiego Kurator Oświaty w Poznaniu przekształcił w poradnie psychologiczno-pedagogiczne (PPP) ${ }^{57}$. Natomiast na bazie dotychczasowej WPWZ w Poznaniu (przeniesionej

\footnotetext{
${ }^{54}$ Regulamin Organizacyjny Pracowni Psychologii Szkolnej Zakładu Psychologii Rozwojowej $i$ Wychowawczej Instytutu Psychologii Uniwersytetu im. A. Mickiewicza i Okręgowej Poradni Wychowawczo-Zawodowej w Poznaniu, w: Psychologiczno-wychowawcze problemy..., red. M. Tyszkowa..., s. 10.

${ }_{55}$ Zob. Psychologiczno-wychowawcze problemy..., red. M. Tyszkowa...; Psychologiczno-wychowawcze problemy szkoły. Materiaty i Sprawozdania Pracowni Psychologii Szkolnej przy Szkole Podstawowej Nr $30 \mathrm{im}$. B. Bieruta, Zeszyty 2 i 3, red. Z. Krążyński, Poznań 1980, 1982.

${ }^{56}$ Aneks do sprawozdania statystycznego GUS za rok szkolny 1980/81 [WPWZ w Poznaniu]; Sprawozdanie opisowe z działalności Wojewódzkiej Poradni Wychowawczo-Zawodowej w Poznaniu za rok szkolny 1981/82, AZ PPP-S w Poznaniu.

${ }^{57}$ Decyzja Nr 124/93 Kuratora Oświaty w Poznaniu z dnia 9 września 1993 r. w sprawie przekształcenia poradni wychowawczo-zawodowych w poradnie psychologiczno-pedagogiczne, AZ PPP w Środzie Wlkp.
} 


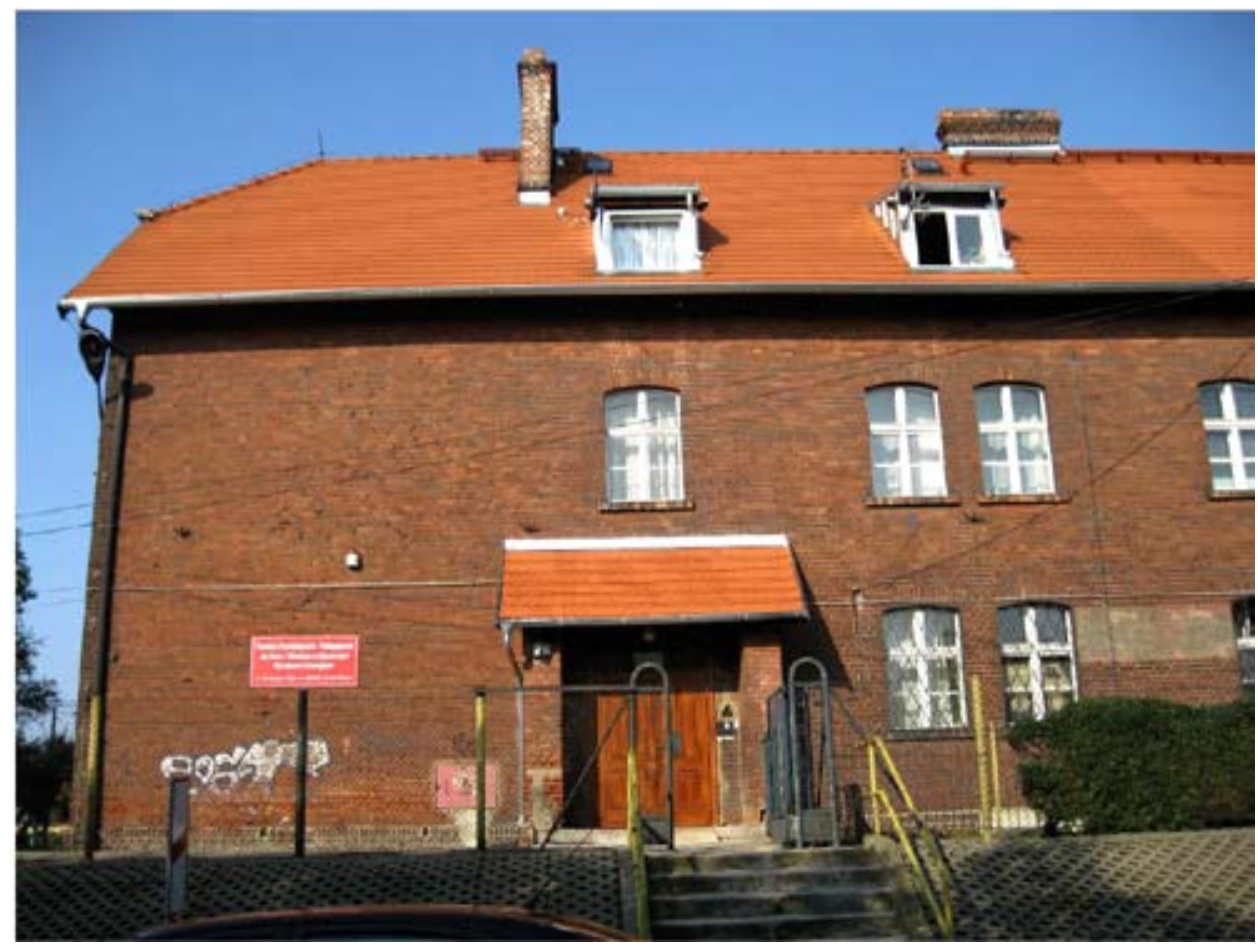

Fot. 3. Siedziba Ośrodka Diagnostyki i Terapii Psychologiczno-Pedagogicznej dla Dzieci i Młodzieży Niepełnosprawnej, obecnie Poradni Psychologiczno-Pedagogicznej dla Dzieci i Młodzieży ze Specjalnymi Potrzebami Edukacyjnymi w Poznaniu, przy ul. 28 Czerwca 1956 r. nr 296/298

Źródło: Zbiory własne autorki.

w 1991 roku do budynku przy ul. 28 Czerwca 1956 r. nr 296/298 - fot. 3) utworzono Ośrodek Diagnostyki i Terapii Psychologiczno-Pedagogicznej dla Dzieci i Młodzieży Niepełnosprawnej (ODiTPP), funkcjonujący na prawach poradni psychologiczno-pedagogicznej ${ }^{58}$. Nie wyznaczono wówczas jednej poradni koordynującej, pełniącej wszystkie zadania dotychczasowej poradni wojewódzkiej. Funkcję tę pełnił wizytator Kuratorium Oświaty w Poznaniu ${ }^{59}$, natomiast zadania szczegółowe rozdzielono. Ośrodkowi powierzono tylko rozpatrywanie odwołań od orzeczeń innych poradni ${ }^{60}$.

${ }^{58}$ Akt likwidacji placówki publicznej nr 45/93 [z dn. 2 czerwca 1993 r., podpisany przez Kuratora Oświaty w Poznaniu Grażynę Ziółkowską], AZ PPP-S w Poznaniu; Akt założycielski placówki publicznej nr 46/93 [z dn. 3 czerwca 1993 r., podpisany przez Kuratora Oświaty w Poznaniu Grażynę Ziółkowską], AZ PPP-S w Poznaniu.

59 Sprawozdanie opisowe z działalności Poradni Psychologiczno-Pedagogicznych województwa poznańskiego w roku szkolnym 1994/1995, AZ KO w Poznaniu, Poradnictwo psychologiczno-pedagogiczne 1993-1997, sygn. $38 / 23$.

${ }^{60}$ Pismo Kuratora Oświaty w Poznaniu nr O.W.I-425/14/93 z dn. 1 września 1993 r. w sprawie powierzenia rozpatrywania odwołań od orzeczeń innych poradni, AZ PPP-S w Poznaniu. 
W 1993 r. celem działalności poradni sformułowanym w Rozporzadzenia MEN z dnia 11 czerwca 1993 r. w sprawie organizacji i zasad działania publicznych poradni psychologiczno-pedagogicznych oraz innych poradni specjalistycznych ${ }^{61}$ stało się wspomaganie rozwoju i efektywności uczenia się dzieci i młodzieży, pomoc uczniom w wyborze kierunku kształcenia i zawodu oraz udzielanie dzieciom i młodzieży, ich rodzicom lub opiekunom, nauczycielom i wychowawcom, pomocy psychologicznej, pedagogicznej, logopedycznej $i$ rehabilitacyjnej ${ }^{62}$. Zadania te realizowano poprzez diagnozę, terapię, doradztwo i profilaktykę. Zakres działań w poszczególnych obszarach wyznaczał statut poradni. Istniała jednak możliwość aby dana poradnia uwzględniała w swojej działalności specyficzny, jednorodny charakter problemów, stając się poradnią specjalistyczną.

Ośrodek Diagnostyki i Terapii Psychologiczno-Pedagogicznej dla Dzieci i Młodzieży Niepełnosprawnej w Poznaniu, działający jako poradnia specjalistyczna, zajmował się przede wszystkim dziećmi z uszkodzeniami słuchu, wzroku i porażeniem mózgowym z szeroko pojmowaną normą intelektualną. Przyjmowano jednak także dzieci niespełniające statutowych kryteriów, np. badane już wcześniej przed wyspecjalizowaniem się placówki lub dzieci z zaburzeniami sprzężonymi wymagające wieloprofilowej terapii, ponieważ tylko Ośrodek zapewniał tak kompleksową pomoc na terenie województwa.

Wśród podstawowej działalności poznańskiej poradni należy wymienić przede wszystkim wielopłaszczyznową diagnozę przyczyn, przebiegu i stanu zaburzeń oraz prowadzenie różnorodnych form terapii grupowej i indywidualnej dzieci z uszkodzeniami zmysłów i ośrodkowego układu nerwowego. Wprowadzono wewnętrzne kwalifikowanie do form terapii (psychologicznej, pedagogicznej, logopedycznej i ruchowej) przekraczającej okres pół roku.

Przykładowo w roku 1993 na terenie poradni były: 4 grupy terapeutyczne dla dzieci z porażeniem mózgowym, $4-\mathrm{z}$ uszkodzeniami słuchu, $1-\mathrm{z}$ uszkodzeniami wzroku i niedokształconą mową, 1 - z zaburzeniami na tle autyzmu. W Szkole Podstawowej dla Niedosłyszących prowadzono 2 grupy orientacji zawodowej. W ramach programu „Praca z dzieckiem z uszkodzeniem, jego rodziną i środowiskiem" funkcjonowały też grupy wsparcia dla rodziców, odbywały się wspólne zajęcia dzieci z rodzicami, prowadzono zajęcia, instruktaż, konsultacje dla nauczycieli. Podjęto współpracę z „Głosem Wielkopolskim” i Fundacją Pomocy Dzieciom Niesłyszącym „Grześ” w zakresie koordynacji tworzonej sieci specjalistycznych gabinetów logopedycznych ${ }^{63}$ oraz szkolenia logopedów na ich potrzeby ${ }^{64}$.

Od roku 1994 utworzono w ośrodku Klub Integracyjny Młodzieży, w którym spotykała się młodzież sprawna i niepełnosprawna. Jego działalność zaowocowała współpracą

${ }^{61}$ Dz. U. 1993, nr 67, poz. 322.

62 Ibidem, $\S 1$ ust. 2.

${ }^{63}$ Sprawozdanie z realizacji zadań Ośrodka Diagnostyki i Terapii Psychologiczno-Pedagogicznej dla Dzieci i Młodzieży Niepetnosprawnej w roku szkolnym 1993/1994; Księga Pamiątkowa Ośrodka Diagnostyki i Terapii Psychologiczno-Pedagogicznej dla Dzieci i Młodzieży Niepetnosprawnej, AZ PPP-S w Poznaniu.

${ }^{64}$ Pismo Dyrektora PPP-S nr PPP-S 140/15/96 z dn. 17 września 1996 r. do Dyrektora PPP w Środzie Wlkp. w sprawie kursu Monachijskiej Funkcjonalnej Diagnostyki Rozwojowej, AZ PPP w Środzie Wlkp. 
międzynarodową z podobną grupą z Sandwell w Anglii. Stworzono bazę techniczną do pracy z wykorzystaniem komputerów. Zakupiono programy do terapii logopedycznej, test MPI oraz szereg programów graficznych i edytor tekstów do stosowania w terapii pedagogicznej ${ }^{65}$. Ponadto przez cały czas do zadań poradni należało: kwalifikowanie do różnych form kształcenia, rozpatrywanie wniosków o zwolnienie z egzaminów wstępnych do szkół ponadpodstawowych, rozpatrywanie odwołań od orzeczeń poradni rejonowych (por. tab. 3).

Możliwość koncentracji na wąskim zakresie problemów w działalności ODiTPP pozwoliła wyspecjalizować się pracownikom tej poradni i pomagać w kwestiach, których nie podejmowały inne placówki. Jej oddziaływania nie były jednak zakrojone na szeroką skalę, nie z powodu małego zapotrzebowania, lecz ze względu na stosunkowo niewielkie zaplecze kadrowo-lokalowe.

Tabela 3. Formy pomocy pośredniej i bezpośredniej udzielonej przez ODiTPP

\begin{tabular}{|c|c|c|c|c|}
\hline \multicolumn{3}{|c|}{ Rodzaj formy udzielonej pomocy } & $1993 / 1994$ & $1994 / 1995$ \\
\hline \multicolumn{5}{|c|}{ Formy udzielonej pomocy pośredniej (liczba orzeczeń i opinii) } \\
\hline \multirow{15}{*}{ 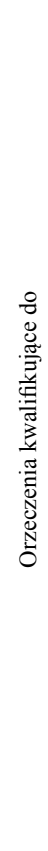 } & \multirow{15}{*}{ 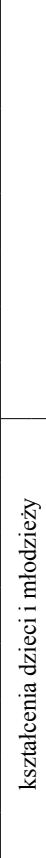 } & indywidualnego nauczania & 46 & 65 \\
\hline & & kształcenia integracyjnego & - & 14 \\
\hline & & $\begin{array}{l}\text { kształcenia w szkołach ponadpodstawowych dla uczniów z problemami } \\
\text { zdrowotnymi }\end{array}$ & - & 19 \\
\hline & & rodzinnych domów dziecka & - & - \\
\hline & & domów dziecka & - & - \\
\hline & & specjalnych ośrodków szkolno-wychowawczych & - & 14 \\
\hline & & placówek resocjalizacyjnych & - & - \\
\hline & & z wadami widzenia & - & 12 \\
\hline & & $\mathrm{z}$ wadami słuchu & 18 & 6 \\
\hline & & upośledzonych umysłowo w stopniu lekkim & 6 & 6 \\
\hline & & upośledzonych umysłowo w stopniu umiarkowanym, znacznym, głębokim & 2 & 10 \\
\hline & & z kalectwem narządu ruchu (od r. 1994/1995 „niepełnosprawnych ruchowo”) & 1 & 3 \\
\hline & & niedostosowanych społecznie, & - & 3 \\
\hline & & z zaburzeniami zachowania, & - & - \\
\hline & & zagrożonych uzależnieniem (rozdzielono od r. 1994/1995) & - & - \\
\hline
\end{tabular}

${ }^{65}$ Sprawozdanie z pracy Ośrodka Diagnostyki i Terapii Psychologiczno-Pedagogicznej dla Dzieci i Młodzieży Niepetnosprawnej w roku szkolnym 1994/1995, AZ PPP-S w Poznaniu. 


\begin{tabular}{|c|c|c|c|}
\hline \multicolumn{2}{|r|}{ Orzekanie o niepełnosprawności dla celów finansowych (tylko w r. 1993/1994) } & 2 & \\
\hline \multicolumn{2}{|r|}{ Wnioski o leczenie zagrożonych uzależnieniem (dodano od r. 1994/1995) } & & - \\
\hline \multicolumn{2}{|c|}{ Wnioski o zwolnienie z egzaminu wstępnego } & 168 & 161 \\
\hline \multirow{8}{*}{ 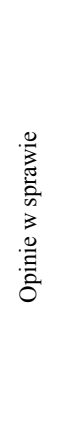 } & skierowania do placówek opiekuńczo-wychowawczych & - & - \\
\hline & przyspieszenia obowiązku szkolnego & 1 & - \\
\hline & odroczenia obowiązku szkolnego & 15 & 13 \\
\hline & udzielenia zezwolenia na indywidualny program lub tok nauki & - & 8 \\
\hline & skierowania do klasy lub szkoły przysposabiającej do pracy zawodowej & - & - \\
\hline & obniżenia wymagań programowych & 15 & 10 \\
\hline & kwalifikowania do klas wyrównawczych i terapeutycznych & - & - \\
\hline & zwolnienia z nauki przedmiotu/ów & 10 & 3 \\
\hline \multicolumn{2}{|r|}{ Inne opinie o przebadanych } & 51 & 64 \\
\hline \multicolumn{4}{|c|}{ Formy pomocy bezpośredniej udzielonej dzieciom i młodzieży (liczba dzieci i młodzieży) } \\
\hline \multirow{10}{*}{ 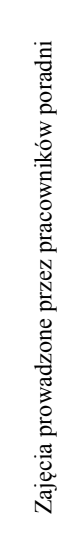 } & zajęcia korekcyjno-kompensacyjne & 22 & 21 \\
\hline & terapia logopedyczna & 22 & 29 \\
\hline & socjoterapia & - & - \\
\hline & zajęcia z uczniami zdolnymi & - & - \\
\hline & terapia dla zagrożonych uzależnieniem & - & - \\
\hline & zajęcia aktywizujące wybór zawodu & 16 & 9 \\
\hline & ćwiczenia usprawniające prowadzone przez rehabilitantów & 7 & 7 \\
\hline & inne formy pomocy indywidualnej & - & 13 \\
\hline & inne formy pomocy grupowej & 53 & 26 \\
\hline & porady bez badań & 3 & 103 \\
\hline \multicolumn{4}{|c|}{ Formy pomocy udzielonej nauczycielom, rodzicom, wychowawcom } \\
\hline \multicolumn{2}{|c|}{ treningi (liczba osób) } & - & - \\
\hline \multicolumn{2}{|c|}{ warsztaty (liczba osób) } & 36 & 39 \\
\hline \multicolumn{2}{|c|}{ terapia rodzin (liczba rodzin) } & 17 & 2 \\
\hline \multicolumn{2}{|c|}{ udział w radach pedagogicznych (liczba spotkań) } & 6 & 9 \\
\hline \multicolumn{2}{|c|}{ prelekcje, wykłady (liczba spotkań) } & 7 & - \\
\hline \multicolumn{2}{|c|}{ inne formy pracy } & 26 & 155 \\
\hline
\end{tabular}

Źródło: Opracowanie własne na podstawie sprawozdań rocznych, AZ PPP-S w Poznaniu. 


\section{Poradnia Psychologiczno-Pedagogiczna dla Dzieci i Młodzieży ze Specjalnymi Potrzebami Edukacyjnymi (1996-2012)}

W 1996 r., po zaledwie trzech latach działalności Ośrodka Diagnostyki i Terapii Psychologiczno-Pedagogicznej dla Dzieci i Młodzieży Niepełnosprawnej, zmieniono jego nazwę na Poradnia Psychologiczno-Pedagogiczna dla Dzieci i Młodzieży ze Specjalnymi Potrzebami Edukacyjnymi (PPP-S) ${ }^{66}$. Jednocześnie, jedynej poradni specjalistycznej w ówczesnym województwie poznańskim, powierzono ponownie wszystkie zadania byłej poradni wojewódzkiej ${ }^{67}$. Kolejne lata przyniosły jednak dalsze zmiany.

Po roku 1999, zgodnie ze zmianami administracyjno-oraganizacyjnymi w całym kraju, poznańska placówka przejęta została przez Urząd Miasta. W 2001 r. powiększono jej rejon działania o wszystkie specjalne placówki oświatowe $\mathrm{z}$ terenu miasta Poznania ${ }^{68}$. Jednak na mocy porozumień zawieranych między lokalnymi samorządami, możliwe było także udzielanie pomocy dzieciom spoza rejonu. Porozumienia z Urzędem Miasta Poznania podpisały powiaty: nowotomyski, międzychodzki, grodziski, średzki i poznański ziemski $^{69}$, do Poznania mogły więc przyjeżdżać także dzieci spoza miasta.

PPP-S funkcjonowała cały czas w siedzibie przy ul. 28 Czerwca 1956 r. nr 296/298, jednak stopniowo władze samorządowe starały się poprawiać jej warunki lokalowe przez remont wnętrza. Natomiast w roku szkolnym 2002/2003 przekazano poradni dodatkowe gabinety po Ośrodku Adopcyjnym i wykonano ich gruntowny remont, co znacznie polepszyło estetykę i funkcjonalność pomieszczeń placówki (fot. 4) ${ }^{70}$.

Poznańska poradnia specjalistyczna kontynuowała działalność ukierunkowaną na udzielanie pomocy dzieciom i młodzieży ze specjalnymi potrzebami edukacyjnymi, a także ich rodzicom i nauczycielom. Obejmowała opieką osoby niepełnosprawne, zwłaszcza z zaburzeniami słuchu, wzroku, uszkodzeniami centralnego i obwodowego układu nerwowego ( $\mathrm{w}$ tym: z mózgowym porażeniem dziecięcym, upośledzeniem umysłowym, zaburzeniami komunikacji językowej o podłożu psychoneurologicznym, przepukliną oponowo-rdzeniową) $)^{71}$. Pomimo podejmowania ograniczonej problematyki istniało zapotrzebowanie na prowadzoną przez nią działalność. Obrazuje to liczba przeprowadzonych w poradni badań diagnostycznych, która wzrosła nawet dwu-, trzykrotnie w ciągu niespełna dziesięciu lat (por. tab. 4).

\footnotetext{
${ }^{66}$ Decyzja Nr 57/96 Kuratora Oświaty w Poznaniu z dnia 22 sierpnia $1996 r$. [w sprawie zmiany nazwy], AZ PPP-S w Poznaniu.

${ }^{67}$ Pismo Kuratora Oświaty w Poznaniu nr OW.I-425/4/96 z dn. 23 sierpnia 1996 r. w sprawie powierzenia zadań dotychczasowej wojewódzkiej poradni wychowawczo-zawodowej, AZ PPP-S w Poznaniu.

${ }^{68}$ Sprawozdanie z pracy Poradni Psychologiczno-Pedagogicznej dla Dzieci i Młodzieży ze Specjalnymi Potrzebami Edukacyjnymi w Poznaniu w roku szkolnym 2001/2002, AZ PPP-S w Poznaniu.

${ }^{69}$ Statut Poradni [ze zmianami], AZ PPP-S w Poznaniu.

70 Sprawozdanie z pracy Poradni Psychologiczno-Pedagogicznej dla Dzieci i Młodzieży ze Specjalnymi Potrzebami Edukacyjnymi w Poznaniu w roku szkolnym 2002/2003, AZ PPP-S w Poznaniu.

71 Pismo Dyrektora PPP-S w Poznaniu z dnia 28.11.2006 r. do Urzędu Miasta Poznania z informacją o działalności poradni, AZ PPP-S w Poznaniu.
} 
Tabela 4. Liczba badań diagnostycznych przeprowadzonych w PPP-S w latach 1999-2008

\begin{tabular}{|c|c|c|c|}
\hline Liczba badan diagnostycznych & psychologicznych & pedagogicznych & logopedycznych \\
\hline $1999 / 2000$ & 418 & 266 & 56 \\
\hline $2000 / 2001$ & 402 & 353 & 82 \\
\hline $2001 / 2002$ & 618 & 489 & 89 \\
\hline $2002 / 2003$ & 787 & 554 & 48 \\
\hline $2003 / 2004$ & 890 & 686 & 120 \\
\hline $2004 / 2005$ & 778 & 593 & 163 \\
\hline $2005 / 2006$ & 850 & 605 & 157 \\
\hline $2006 / 2007$ & 820 & 757 & 697 \\
\hline $2007 / 2008$ & 818 & 697 & 89 \\
\hline
\end{tabular}

Źródło: Opracowanie własne na podstawie sprawozdań rocznych, AZ PPP-S w Poznaniu.

Wzrost liczby badań nie wiązał się ze zwiększaniem zatrudnienia specjalistów. W poznańskiej poradni pracownicy pedagogiczni obejmowali niemal przez cały czas 16 etatów (zamiennie po 7,5-8,5 etatów pedagogów i psychologów). Dopiero w 2004 r. zwiększono liczbę etatów, ale zaledwie o jeden ${ }^{72}$.

Pracownicy poradni realizowali wobec zgłaszających się klientów dostępne formy pomocy pośredniej i bezpośredniej, zgodnie z obowiązującymi w tym zakresie przepisami. Postępowania diagnostyczne najczęściej kończyły się wydaniem orzeczenia o potrzebie kształcenia specjalnego lub odpowiedniej opinii, stosownie do obowiązujących w danym okresie przepisów. W latach 1999-2001 poradnia w Poznaniu najczęściej kwalifikowała do indywidualnego nauczania oraz do kształcenia w szkołach ponadpodstawowych dla uczniów z problemami zdrowotnymi. Stosunkowo często wydawała również opinie zobowiązujące szkoły do obniżenia wymagań programowych lub zawierające wskazania do pracy z danym uczniem (inne opinie o przebadanych).

Po zmianach w przepisach oświatowych i wyszczególnieniu nowych kategorii orzeczeń i opinii, w latach 2001-200473, nadal utrzymały się dotychczasowe tendencje w za-

72 Na podstawie sprawozdań rocznych PPP-S w Poznaniu, AZ PPP-S w Poznaniu.

73 Zob. Rozporządzenie MEN z dnia 15 stycznia 2001 r. w sprawie szczegółowych zasad działania publicznych poradni psychologiczno-pedagogicznych i innych publicznych poradni specjalistycznych oraz ramowego statutu tych poradni (Dz. U. 2001, nr 13, poz. 109); Rozporządzenie MENiS z dnia 11 grudnia 2002 r. w sprawie szczegółowych zasad działania publicznych poradni psychologiczno-pedagogicznych, w tym publicznych poradni specjalistycznych (Dz. U. 2003, nr 5, poz. 46); Rozporządzenie Ministra Edukacji Narodowej i Sportu z dnia 11 grudnia 2002 r. w sprawie ramowego statutu publicznej poradni psychologiczno-pedagogicznej, w tym publicznej poradni specjalistycznej (Dz. U. 2002, nr 223, poz. 1869); Rozporządzenie Ministra Edukacji Narodowej i Sportu z dnia 7 stycznia 2003 r. w sprawie zasad udzielania i organizacji pomocy psychologiczno-pedagogicznej w publicznych przedszkolach, szkołach i placówkach (Dz. U. 2003, nr 11, poz. 114); Rozporządzenie Ministra Edukacji Narodowej i Sportu z dnia 29 stycznia 2003 r. zmieniające roz- 


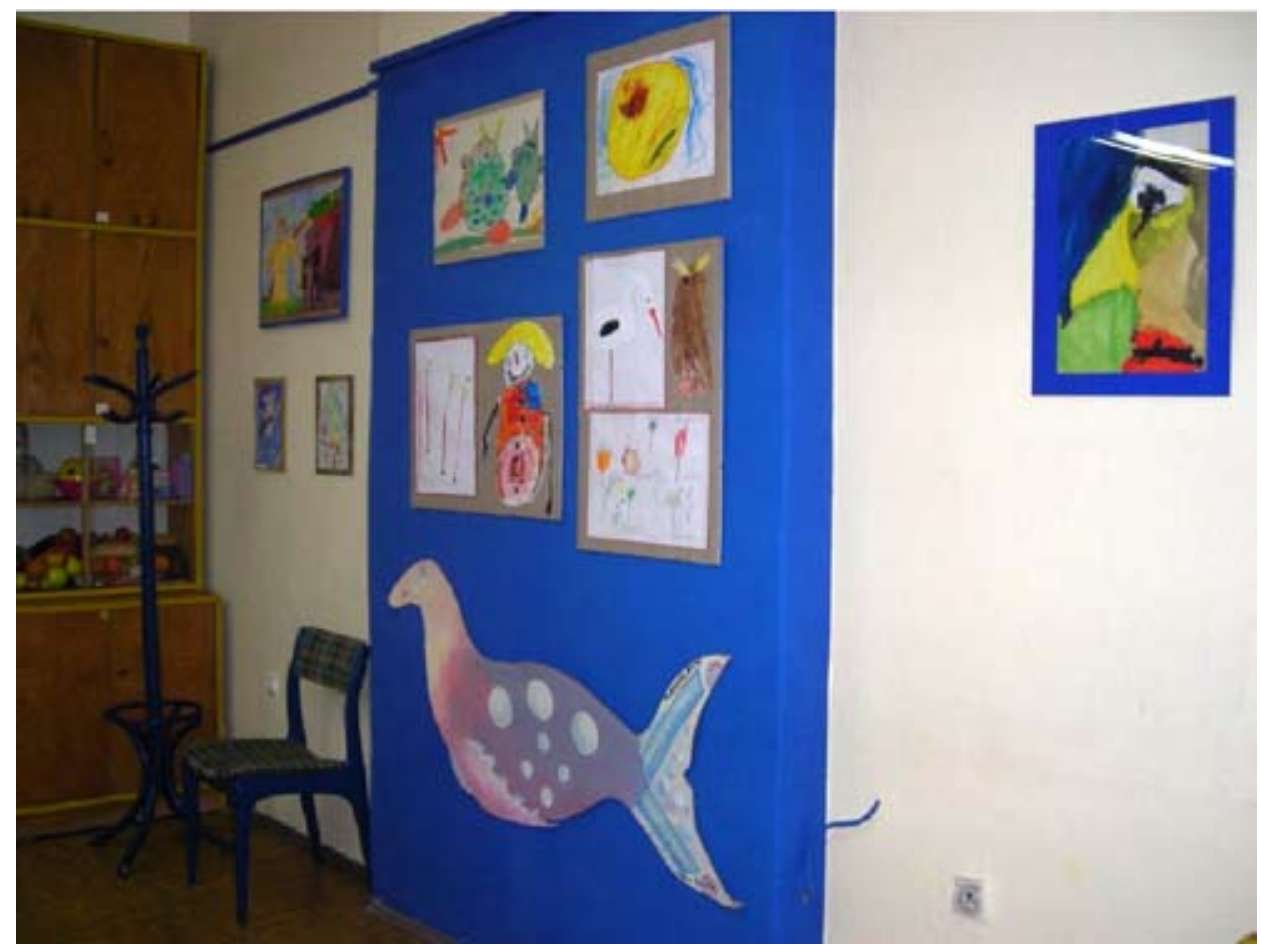

Fot. 4. Wnętrze Poradni Psychologiczno-Pedagogicznej dla Dzieci i Młodzieży ze Specjalnymi Potrzebami Edukacyjnymi w Poznaniu

Źródło: [online], http://www.ppp-s.poznan.pl/index2.php [dostęp 26.01.2010].

kresie najczęściej wydawanych dokumentów. Poza tym znacząco wzrosła liczba uczniów kwalifikowanych do kształcenia specjalnego dla upośledzonych umysłowo w stopniu lekkim, umiarkowanym lub znacznym. Bardzo często opiniowano również w sprawie dysfunkcji u uczniów podchodzących do egzaminów na końcu poszczególnych etapów edukacyjnych.

Po roku 2004 znacząco wzrosła liczba wydanych orzeczeń i opinii w większości kategorii. Do poradni zgłosiło się więcej dzieci z różnymi rodzajami niepełnosprawności, które kwalifikowano do odpowiedniego kształcenia specjalnego. Nadal często orzekano potrzebę indywidualnego nauczania. Liczne pozostały opinie w sprawie dostosowania wymagań edukacyjnych podczas zajęć lekcyjnych oraz warunków i formy egzaminów do indywidualnych potrzeb edukacyjnych ucznia.

porządzenie w sprawie orzekania o potrzebie kształcenia specjalnego lub indywidualnego nauczania dzieci i młodzieży oraz szczegółowych zasad kierowania do kształcenia specjalnego lub indywidualnego nauczania (Dz. U. 2003, nr 23, poz. 192) i inne. 
Zwraca uwagę liczba orzeczeń uchylających wydawanych przez PPP-S w Poznaniu, zwłaszcza w kontekście poruszanej wówczas w poradnictwie problematyki nierzetelności diagnozy i kwalifikacji do szkolnictwa specjalnego ${ }^{74}$. Po stwierdzeniu, że części uczniów kończących szkoły specjalne nie można kwalifikować do kształcenia specjalnego w kolejnym etapie edukacyjnym, konieczne było wydanie orzeczeń uchylających lub odmownych. Na szczęście podjęto kroki zmierzające do udzielenia pomocy uczniom. Dla osób, którym PPP-S nie mogła wydać po zakończeniu gimnazjum specjalnego kolejnego orzeczenia kwalifikującego je do szkoły zawodowej specjalnej, tworzono klasy wyrównawcze lub klasy terapeutyczne w szkołach masowych.

$\mathrm{Z}$ analizy corocznych sprawozdań wynika, że punkt ciężkości położono na działalność diagnostyczną oraz wynikające $\mathrm{z}$ niej orzecznictwo i opiniowanie. W mniejszym zakresie, ale udzielano oczywiście pomocy bezpośredniej, np. w formie zajęć korekcyjno-kompensacyjnych, terapii logopedycznej oraz innych form pomocy indywidualnej i grupowej. Ważną inicjatywą było prowadzenie badań gotowości szkolnej dzieci z przedszkoli integracyjnych oraz monitorowanie losów edukacyjnych uczniów skierowanych do klas integracyjnych. Przez cały okres realizowano także na terenie poradni grupowe zajęcia stymulujące rozwój, w oparciu o arteterapię. Od roku szkolnego 2002/2003 rozszerzono ofertę terapeutyczną placówki, tworząc gabinet do terapii metodą integracji sensorycznej ${ }^{75}$.

Tym, co szczególnie wyróżniało poznańską poradnię specjalistyczną była szeroka działalność na rzecz otoczenia dziecka i współpraca z instytucjami z lokalnego środowiska. Pracownicy poradni prowadzili liczne warsztaty, prelekcje, wykłady dla rodziców i nauczycieli, szkolili rady pedagogiczne, zapraszani byli na konferencje i sami je organizowali. Przygotowywali także materiały edukacyjne, np.: opracowanie dla nauczycieli pt. „Funkcjonowanie dziecka z mózgowym porażeniem dziecięcym w warunkach szkoły ogólnodostępnej”, broszurę dla rodziców pt. Co rodzic powinien wiedzieć o dojrzałości szkolnej siedmiolatka, informator pt. Alfabetyczny spis zawodów najbardziej dostępnych dla uczniów szkolnictwa specjalnego z terenu miasta Poznania i powiatu poznańskiego. W PPP-S w Poznaniu dokonano pionierskiej pracy przygotowania dla potrzeb dzieci niewidomych testów pedagogicznych w alfabecie Braille'a oraz prób do badania percepcji dotykowej, orientacji przestrzennej i znajomości alfabetu zgodnie z zasadami nauki Braille'a.

Organizowano także spotkania z przedstawicielami instytucji pracujących w Poznaniu na rzecz dzieci niepełnosprawnych (np. Polski Związek Głuchych, Ośrodek SzkolnoWychowawczy dla Dzieci Niesłyszących, Klinika Laryngologii) w celu poznania zakresu działalności oraz wymiany doświadczeń. We współpracy z niektórymi podejmowano nowe różnorodne inicjatywy, jak np. staż dwóch pracowników poradni w ośrodku rehabilitacji dzieci z wadą słuchu w Holandii; grupa terapeutyczna dla dzieci z zespołem

${ }^{74}$ Por. Protokól z Rady Pedagogicznej dyrektorów Poradni Psychologiczno-Pedagogicznych z dnia 11.04.2002 r., AZ KO w Poznaniu, Protokoły z narad dyrektorów PPP, sygn. 2/2.

75 Por. Sprawozdania z pracy Poradni Psychologiczno-Pedagogicznej dla Dzieci i Młodzieży ze Specjalnymi Potrzebami Edukacyjnymi w Poznaniu za lata 1999-2008, AZ PPP-S w Poznaniu. 
Downa i ich rodziców w odpowiedzi na zapotrzebowanie Stowarzyszenia Pomocy Osobom z Zespołem Downa; wykłady dla Klubu Rodziców Dzieci Niewidomych i Słabowidzących przy Polskim Związku Niewidomych ${ }^{76}$.

W okresie lat 2001-2012 poradnia szczególnie często musiała dostosowywać swoją działalność do zmieniających się oświatowych aktów prawnych. Musiała wpisywać się $\mathrm{W}$ założenia reformowanego systemu pomocy psychologiczno-pedagogicznej z lat 2001-2003 ${ }^{77}$, zakładającego większą swobodę organizacyjną, interdyscyplinarność i ponadresortowość działań, zwłaszcza na poziomie samorządu terytorialnego. W roku 2010 ponownie zdefiniowano jej zadania i miejsce w systemie pomocy psychologiczno-pedagogicznej $^{78}$. Po raz kolejny rozszerzono katalog realizowanych przez nią zadań, zaznaczając, że nie jest on zamknięty, ponieważ oferta poradni musi odpowiadać na konkretne zapotrzebowanie środowiska, powinna być spójnym elementem lokalnego systemu wsparcia. Szczególny nacisk został położony na ścisłą współpracę z rodzicami, przedszkolami, szkołami i innymi placówkami świadczącymi pomoc psychologiczno-pedagogiczną.

W roku 2012 Poradnia Psychologiczno-Pedagogiczna dla Dzieci i Młodzieży ze Specjalnymi Potrzebami Edukacyjnymi funkcjonowała nadal jako poradnia specjalistyczna, ukierunkowana na specyficzny, jednorodny charakter problemów. Swoją ofertę pomocy zwracała do dzieci i młodzieży niepełnosprawnej, szczególnie dzieci z uszkodzeniami słuchu, wzroku, narządów ruchu i z upośledzeniem umysłowym; a także do ich rodziców i nauczycieli. Podstawowe zadania poradni to:

- wspieranie rozwoju dzieci i młodzieży, zmierzajace do ich możliwie petnego uczestnictwa we wszystkich formach życia społecznego,

- profilaktyka trudności i niepowodzeń szkolnych dziecka wynikajacych z jego niepetnosprawności, bądź zaburzeń rozwojowych,

- diagnoza i orzecznictwo nastawione na pomoc $w$ doborze właściwych form ksztatcenia i przygotowania zawodowego,

${ }^{76}$ Ibidem.

77 Zob. przypis 73.

${ }^{78}$ Zob. Rozporządzenie MEN z dnia 17 listopada 2010 r. w sprawie szczegółowych zasad działania publicznych poradni psychologiczno-pedagogicznych, w tym publicznych poradni specjalistycznych (Dz. U. 2010, nr 228, poz. 1488); Rozporządzenie MEN z dnia 17 listopada 2010 r. zmieniające rozporządzenie w sprawie ramowego statutu publicznej poradni psychologiczno-pedagogicznej, w tym publicznej poradni specjalistycznej (Dz. U. 2010, nr 228, poz. 1492); Rozporządzenie MEN z dnia 17 listopada 2010 r. w sprawie zasad udzielania i organizacji pomocy psychologiczno-pedagogicznej w publicznych przedszkolach, szkołach i placówkach (Dz. U. 2010, nr 228, poz. 1487); Rozporządzenie MEN z dnia 17 listopada 2010 r. w sprawie warunków organizowania kształcenia, wychowywania i opieki dla dzieci i młodzieży niepełnosprawnych oraz niedostosowanych społecznie w specjalnych przedszkolach, szkołach i oddziałach oraz w ośrodkach (Dz. U. 2010, nr 228, poz. 1489); Rozporządzenie MEN z dnia 17 listopada 2010 r. w sprawie warunków organizowania kształcenia, wychowania i opieki dla dzieci i młodzieży niepełnosprawnych oraz niedostosowanych społecznie w przedszkolach, szkołach i oddziałach ogólnodostępnych lub integracyjnych (Dz. U. 2010, nr 228, poz. 1490); Rozporządzenie MEN z dnia 17 listopada 2010 r. zmieniające rozporządzenie w sprawie warunków i sposobu oceniania, klasyfikowania i promowania uczniów i słuchaczy oraz przeprowadzania sprawdzianów i egzaminów w szkołach publicznych (Dz. U. 2010, nr 228, poz. 1491). 
- udzielanie pomocy merytorycznej oraz wsparcia nauczycielom, wychowawcom, psychologom i pedagogom pracujacym z dziećmi niepetnosprawnymi w szkolnictwie specjalnym, masowym i placówkach opiekuńczo-wychowawczych,

- udzielanie wsparcia metodycznego i emocjonalnego rodzicom/opiekunom dzieci i mtodzieży niepetnosprawnych,

- wydawanie orzeczeń $i$ opinii dla potrzeb oświatowych ${ }^{79}$.

W poradni funkcjonowało 6 zespołów diagnostyczno-terapeutycznych do spraw: upośledzonych umysłowo, niepełnosprawnych ruchowo, słabosłyszących i niesłyszących, słabowidzących i niewidomych, poradnictwa zawodowego, terapii grupowej. Poszczególne zespoły zajmowały się określonym zagadnieniem, obejmując opieką dzieci i młodzież z danym problemem oraz współpracując z ich rodzicami, opiekunami, placówkami oświatowymi. Ponadto, poza standardowymi, opisanymi już wcześniej, formami pomocy pośredniej i bezpośredniej, poradnia oferowała także: diagnozę i terapię SI (integracja sensoryczna), terapię logopedyczną, psychologiczną pomoc terapeutyczna, trening EEG biofeedback, zajęcia psychoedukacyjne „Szkoła dla rodziców”.

Rok 2012 był dla Poradni Psychologiczno-Pedagogicznej dla Dzieci i Młodzieży ze Specjalnymi Potrzebami Edukacyjnymi w Poznaniu rokiem szczególnym. Minęło wówczas 55 lat od momentu rozpoczęcia działalności pod nazwą Poradnia Psychologiczna w Poznaniu. Placówka podlegała przez te lata licznym reformom administracyjnym, oświatowym, systemu pomocy psychologiczno-pedagogicznej. Czterokrotnie nadawano nową nazwę poradni, wiele razy definiowano zakres zadań, nieustannie je poszerzając; zmieniały się organy prowadzące i obszar oddziaływania. Niezaprzeczalnie jednak zawsze pełniła niezwykle istotną funkcję wobec dzieci i młodzieży objętych jej opieką udzielała pomocy.

\section{Bibliografia}

Materiały archiwalne

Archiwum Akt Nowych w Warszawie: Zespół Ministerstwo Oświaty w Warszawie (sygn. 674).

Archiwum Kuratorium Oświaty w Poznaniu: Zespół Poradnictwo psychologiczno-pedagogiczne 2000-2003 (sygn. 198/423); Zespół Poradnictwo psychologiczno-pedagogiczne 1993-1997 (sygn. 38/23); Zespół Protokoły z narad dyrektorów PPP (sygn. 2/2).

Archiwum Państwowe w Poznaniu: Zespół Prezydium Wojewódzkiej Rady Narodowej (sygn. 3978).

Archiwum Zakładowe Poradni Psychologiczno-Pedagogicznej dla Dzieci i Młodzieży ze Specjalnymi Potrzebami Edukacyjnymi (bez sygn.).

Archiwum Zakładowe Poradni Psychologiczno-Pedagogicznej w Środzie Wlkp. (bez sygn.).

Archiwum Zarządu Głównego Towarzystwa Przyjaciół Dzieci w Warszawie - Helenowie: (sygn. I 37/9, I 3J/12.

\footnotetext{
${ }^{79}$ Strona internetowa Poradni Psychologiczno-Pedagogicznej dla Dzieci i Młodzieży ze Specjalnymi Potrzebami Edukacyjnymi, http://www.ppp-s.poznan.pl/cms/?,9, stan z dn. 30.11.2012 r.
} 


\section{Źródła drukowane}

Dziennik Urzędowy Ministerstwa Oświaty (1957, 1958, 1964).

Dziennik Urzędowy Ministerstwa Oświaty i Szkolnictwa Wyższego (1968).

Dziennik Urzędowy Ministerstwa Oświaty i Wychowania (1973).

Dziennik Ustaw Polskiej Rzeczypospolitej Ludowej $(1961,1975)$.

Dziennik Ustaw Rzeczypospolitej Polskiej (1993, 2001; 2002; 2003; 2010).

Chcesz wybrać zawód - szkotę - pracę? Przeczytaj, Poznań 1977.

Materiały - Informacje - Sprawozdania Regionalnej Izby Pamiątek Oświatowych, z. 7, Poznań 1990.

Psychologiczno-wychowawcze problemy szkoły. Materiaty i sprawozdania Pracowni Psychologii Szkolnej przy Szkole Podstawowej Nr 30, red. M. Tyszkowa, z. 1, Poznań 1977.

Psychologiczno-wychowawcze problemy szkoły. Materiaty i Sprawozdania Pracowni Psychologii Szkolnej przy Szkole Podstawowej Nr 30 im. B. Bieruta, Zeszyty 2 i 3, red. Z. Krążyński, Poznań 1980, 1982.

Zanim podejmiesz decyzję o wyborze zawodu i pracy poczytaj, Urząd Wojewódzki w Poznaniu Wydział Zatrudnienia i Spraw Socjalnych, Wojewódzka Poradnia Wychowawczo-Zawodowa w Poznaniu, Poznań 1984.

\section{Źródła wywołane}

Wywiad z dnia 16.09.2008 r. z Janem Wojtaszkiem - dyrektorem Okręgowej (później Wojewódzkiej) Poradni Wychowawczo-Zawodowej w Poznaniu.

Wywiad z dnia 16.07.2009 r. z Marianem Bolewskim - wieloletnim pracownikiem i kierownikiem placówek poradnictwa w Kole.

\section{Źródła elektroniczne}

Strona internetowa Poradni Psychologiczno-Pedagogicznej dla Dzieci i Młodzieży ze Specjalnymi Potrzebami Edukacyjnymi, www.ppp-s.poznan.pl/cms/?,9, stan z dn. 30.11.2012 r.

\section{Artykuły i czasopisma}

Obuchowski K., Analiza i ocena stanu psychologii klinicznej w dwudziestym roku Polski Ludowej, „Przegląd Psychologiczny” 1965, nr 10.

„Problematyka Poradnictwa Wychowawczego oraz Orientacji Szkolnej i Zawodowej”, 1973-1989, nr $1-13$.

\section{Opracowania}

Orientacja i poradnictwo zawodowe w szkole podstawowej, red. W. Rachalska, Warszawa 1980.

Poradnictwo wychowawczo-zawodowe $w$ systemie oświaty $i$ wychowania. Materiały z konferencji wieńczacej XX lecie poradnictwa wychowawczo-zawodowego $w$ województwie poznańskim 23.X.1978 r., Poznań 1979. 
Szajek S., Orientacja i poradnictwo zawodowe, Warszawa 1979.

Szajek S., Problemy zawodoznawcze w szkole podstawowej, w: Psychologiczne i pedagogiczne problemy poradnictwa zawodowego, Warszawa 1975. 